\title{
Rámce a roviny krivých obvinení zo sexuálneho zneužívania detí
}

\section{Frames and Levels of False Allegations of Child Sexual Abuse}

\author{
Slávka Karkošková**, Gabriela Mikulášková***
}

\begin{abstract}
Abstrakt
Štúdia sa venuje otázke výskytu sexuálneho zneuživania detí (CSA) a problému latencie. Upozorñuje, že pri úsili o identifikáciu prípadov CS A brozi dvojaké riziło mylných záverov (mylne pozitíne a mylne negatíne závery). Zdôražnuje, že nepodložené a nepravdivé obvinenia nie sú synonymom krivých obvinení a ponúka prierez teoretickým modelom ciest ke nepravdivým obvineniam z. CS A. Sumarizuje výsledky a limity zabraničných výskumov o výskyte krivých obvineni z. CS A. Objasñuje pré̌o profesionálna skúsenost' ani systematické metódy posudzovania vierohodnosti výpovede nie sú spol'ablivými nástrojmi na odhalenie krivých obvineni z. CSA. Pobáda k obozretnosti pred trúfalými turdeniami o výskyte krivých obvineni z. CSA.
\end{abstract}

\section{Kl'účové slová}

Sexuálne żneu:̌ivivanie detí (CSA); krivé obvinenia; nepravdivé obvinenia.

\begin{abstract}
The study addresses the question of child sexual abuse (CSA) prevalence and the issue of its latency. It highlights that an effort to identify CS A cases is exposed to a double risk of false conclusions (false positive and false negative conclusions). It stresses that unsubstantiated and untrue allegations are not synonymous to false allegations and it offers an overview of a theoretical model of pathways toward untrue allegations of CSA. The study summarizes the results and limits of foreign research on prevalence of false accusations of CSA. It clarifies why neither experts' experience nor systematic methods of victim statement credibility assessment are fully reliable tools for false CSA allegations detection. It encourages prudent attitude toward confident claims regarding the occurrence of false CSA allegations.
\end{abstract}

\section{Keywords}

Child sexual abuse (CSA); False allegations; Untrue allegations.

* Náčrt obsahu tejto štúdie bol prvotne stručne prezentovaný v sekcii 1 Ústavnoprávne, zákonné a kriminologické atribúty o obetiach trestných činov na konferencii Bratislavské právnické fórum 2018 - Súdnictvo ako garant hodnôt demokratického a práuneho śtátu, ktorá sa konala v termíne 22. a 23. februára 2018 na pôde Právnickej fakulty Univerzity Komenského v Bratislave.

Táto práca bola podporovaná Agentúrou na podporu výskumu a vývoja na základe zmluvy č. APVV-16-0471 / This work was supported by the Slovak Research and Development Agency under the contract No. APVV-16-0471.

** Doc. ThDr. Mgr. Slávka Karkošková, PhD., Justičná akadémia Slovenskej republiky; Vysoká škola zdravotníctva a sociálnej práce sv. Alžbety, n.o. / The Judicial Academy of the Slovak Republic; St. Elizabeth University of Health and Social Work / E-mail: slavka.karkoskova@gmail.com

*** Doc. PhDr. Gabriela Mikulášková, PhD., Justičná akadémia Slovenskej republiky; Inštitút psychológie, Filozofická fakulta Prešovskej univerzity v Prešove / The Judicial Academy of the Slovak Republic; Institute of Psychology, Faculty of Arts at the University of Presov / E-mail: gabriela.mikulaskova@unipo.sk 


\section{Úvod}

Pri rôznych príležitostiach (ako sú vzdelávacie semináre či odborné a vedecké konferencie) sa prvá autorka tejto štúdie opakovane stretla s tým, že čast’ profesionálov predpokladá alebo konštatuje vysoký výskyt krivých obvinení z CSA na Slovensku, najmä v kontexte poručenských sporov. Zároveň sa v poslednom období čoraz častejšie objavujú mediálne výstupy pseudo-odborného alebo odborno-populárneho charakteru ${ }^{1}$, ktoré takéto názory efektívne distribuujú, ponúkajúc rýchle a jasné odpovede na komplikovaný problém.

Ako členky výskumného tímu v projekte Sexuálne zneuživanie deti a zverených osôb (APVV16-0471) sme sa na problematiku krivých obvinení z CSA rozhodli pozriet' dôkladnejšie. V predkladanej štúdii prinášame prehl’ad najaktuálnejších vedeckých poznatkov, ktoré osvetl'ujú v akých rámcoch a rovinách je predmetná problematika ponímaná.

Štúdia môže byt' užitočná tak pre trestných sudcov ako aj pre sudcov, ktorí sa venujú poručenskej agende. Obe skupiny primárnych adresátov môže pobádat’ k reflexii nad tým, ako sa pri posudzovaní predmetných prípadov vysporadúvajú s dvoma kl’účovými princípmi - principom prezumpcie neviny a principom prezumpcie statusu obete ${ }^{2}$. Reflexia tohto

1 V tejto súvislosti je potrebné reflektovat' riziká spojené s tzv. post-pravdivou dobou, v ktorej žijeme. Termín post-pravdivý (post-truth) je definovaný ako ,privlastok týkajúci sa alebo označujúci okolnosti, v ktorých sú objektivine fakty menej dôležité pri formovani verejnej mienky, než apel na emócie a osobné presvedčenia" (Word of the Year 2016 is... [online]. Oxford University Press, 2017 [cit. 4.1.2018]. Dostupné z: https:// en.oxforddictionaries.com/word-of-the-year/word-of-the-year-2016). Žial', tento fenomén prenikol aj do sveta vedy, preto orientácia v odborných a vedeckých výstupoch v súčasnosti kladie zvýšené nároky na kritické myslenie (RYDBERG, Jenny Ann. Research and clinical issues in trauma and dissociation: Ethical and logical fallacies, myths, misreports, and misrepresentations. European Journal of Trauma \& Dissociation, 2017, roč. 1, č. 2, s. 89-99).

2 Princíp prezumpcie statusu obete (JELÍNEK, Jiří, Tomáš GŘIVNA et al. Poškozený a obèt’ trestného činu z trestnèprávního a kriminologickébo pohledu. Praha: Leges, 2012, 256 s., s. 26. ISBN 978-80-87576-39-7; ZÁHORA, Jozef. Zákon o obetiach trestných činov: Komentár. Bratislava: Wolters Kluwer, 2018, 416 s., s. 109 110. ISBN 978-80-8168-850-8) vyplýva pôvodne z dokumentu OSN z roku 1985 (Deklarácia základných principov spravodlivosti pre obete trestných činov a zneuritia právomoci / Declaration of Basic Principles of Justice for Victims of Crime and Abuse of Power [online]. A/RES/40/34 [cit. 2.2.2018]. Dostupné z: http://www. un.org/documents/ga/res/40/a40r034.htm) a je reflektovaný aj v Smernici Európskeho parlamentu a rady 2012/29/ EÚ ₹ 25. októbra 2012, ktorou sa stanovijú minimálne normy v oblasti práv, podpory a ochrany obetí trestných činov, bod 19 preambuly, podl'a ktorého ,osoba by sa mala považovat' za obet' bez obl'adu na skutočnost', 'í bol páchatel' identifikovaný, zaistený, stíhaný alebo odsúdený, a bez obl'adu na rodinný vz̨tah medzi nimi." V slovenskej legislatíve je vymedzený nasledovne: „Každá osoba, ktorá turdí, že je obet’ou, sa považuje za obet’, kým sa nepreukáže opak, alebo ak nejde o zjavné zneuřitie postavenia obete podl'a tobto zákona, a to bez obl'adu na to, či bol páchatel' trestného činu zistený, trestne stíhaný alebo odsúdeny’ (Zákon č. 274/ 2017 Z.z. Zákon o obetiach trestných činov a o zmene a doplnení niektorých zákonov, \$ 3, ods. 1). „Ak vanikne pochybnost’o statuse obete, je potrebné sa priklonit' k záveru, že táto osoba je obet’ou trestnébo činu. K preukázaniu „opaku“ "môžze dôjst'v priebehu trestnébo konania, ked'je celkom zrejmé, že sa nestal trestný čin, resp. skutok nie je trestným činom. (...) Na drubej strane, samotné prehlásenie osoby, že sa necíti byt’ obetou trestného činu, nemôže bez d'alšieho viest' k ignorovaniu statusu obete zo strany prislušných subjektov. (...) Odopretie statusu obete v dôsledku nesprávneho posúdenia mồze mat' za následok možnost' uplatnenia zodpovednosti státu za nesprávny úradný postup podla zákona č. 514/2003 Z. z. o zodpovednosti za škodu spôsobenú pri výkone verejnej moci" (ZÁHORA, op. cit., s. 109-110). 
druhu môže byt' rovnako užitočná aj pre prokurátorov, policajných vyšetrovatel'ov, súdnych znalcov, sociálnych pracovníkov zaoberajúcich sa sociálno-právnou ochranou detí, advokátov, či iných profesionálov, ktorí sa s prípadmi podozrení z CSA stretávajú a zaujímajú $\mathrm{k}$ nim postoje.

\section{Možnosti a limity identifikácie CSA}

\subsection{Prevalencia CSA}

Sexuálne zneužívanie detí (d’alej len CSA, z angl. child sexual abuse) patrí medzi najzávažnejšie sociálno-patologické javy, s potenciálom celého spektra dlhodobých negatívnych následkov na kvalitu života obetí. Stanovenie presného odhadu výskytu (prevalencie) CSA je vel'mi náročné pretože relevantné výskumy (retrospektívneho charakteru) majú značné metodologické odlišnosti. ${ }^{3}$ Hlavné odlišnosti sa týkajú predovšetkým samotnej definície CSA, ktorá sa v jednotlivých výskumoch môže líšit' v niekol'kých aspektoch:

a) horná veková hranica detstva (v rôznych štúdiách sa pohybuje od 15 do 18 rokov),

b) či je alebo nie je stanovený minimálny vekový rozdiel medzi obet’ou a páchatel’om (niektoré štúdie nestanovujú žiadne obmedzenie, iné za páchatel’a považujú iba osobu od obete staršiu minimálne o 3-5 rokov, a d’alšie štúdie reflektujú CSA iba ak páchatel’ bol dospelý),

c) úroveň kontaktu, ktorá kvalifikuje incident ako CSA (niektoré štúdie berú do úvahy iba penetratívne formy CSA, iné zohl'adňujú aj široké spektrum dotykových a bezdotykových foriem CSA, čo sa premieta aj v počte a špecifickosti otázok, ktorými sa výskumníci pýtajú respondentov na CSA).

Okrem toho sú odlišné údaje o prevalencii CSA podmienené aj metodológiou výberu vzorky respondentov (napr. náhodný výber zo všeobecnej populácie verzus klinická populácia), vekom respondentov (pubescenti, adolescenti, dospelî) a dizajnom výskumu (najmä pokial ide o mieru súkromia, ktorá je respondentom pri dopytovaní poskytnutá).

Vzhl’adom na uvedené metodologické odlišnosti výskumov nie je prekvapujúce, že vedecká literatúra ponúka vel’mi odlišné údaje o prevalencii CSA. Podl’a jednej z najnovších metaanalýz ${ }^{4}$ sa globálny výskyt CSA pohybuje v rozmedzí od 8 do $31 \%$ u žien a od 3 do $17 \%$ u mužov. ${ }^{5}$ Výsledky vybraných štúdií pochádzajúcich z 11 krajín Európy ukazujú, že penetratívne formy CSA zažilo 2,9-10,5\% dievčat a 0,6-5,5 \%

3 KARKOSKOVA, Slavka a Ivan ROPOVIK. The prevalence of child sexual abuse among Slovak late adolescents. [online]. 2018, s. 3-4 [cit. 25.3.2018]. DOI: 10.17605/OSF.IO/D8BG6. Dostupné z: http://osf.io/ preprints/socarxiv/d8bg6

4 Metaanalýza je vedecká metóda, ktorá spočíva v sumarizácii a syntéze výsledkov rozličných štúdií zaoberajúcich sa rovnakou problematikou. Má omnoho vyšší stupeň vierohodnosti než jednotlivé štúdie.

5 BARTH, Jürgen, Lilian BERMETZ, Eva HEIM, Sven TRELLE a Thomy TONIA. The current prevalence of child sexual abuse worldwide: a systematic review and meta-analysis. International Journal of Public Health, 2013, roč. 58, č. 3, s. 469-483. 
chlapcov; zatial čo pri použití širšej definície kontaktných foriem CSA sa ich výskyt pohyboval v rozpätí 10-39,8 \% u dievčat a 6-16,2 \% u chlapcov. ${ }^{6}$ Podl'a najnovšieho Slovenského výskumu do dovŕšenia 18-roku veku sa penetratívne formy CSA vyskytli u 5,6 \% dievčat a 1,3\% chlapcov, dotykové formy CSA zažilo až 30,2 \% dievčat a 11,6 \% chlapcov a skúsenost' s nedotykovými formami $\mathrm{CSA}^{7}$ priznalo 40,6 \% dievčat a 17,7\% chlapcov. Viac ako polovica ,incidentov“ CSA sa odohrala v postpubescentnom období. ${ }^{8}$ Hoci sa možno stretnút's tvrdeniami, že prevalencia CSA sa preháňa kvôli zbytočne širokým definíciám CSA, treba zdôraznit', že longitudinálne výskumy týkajúce sa zdravotných dôsledkov odôvodňujú používanie širokých definícii CSA. Vysoká prevalencia zdanlivo menej závažných foriem CSA by sa nemala trivializovat'. Aj nedotykové formy CSA totiž môžu mat' negatívne následky na zdravie obeti1 ${ }^{10}$, najmä ak k nim dochádza opakovane ${ }^{11}$.

\subsection{Miera latencie a riziko mylných záverov pri identifikácii CSA}

Skutočnost', že o prevalencii CSA nemá verejnost' dostatočné povedomie, je pravdepodobne podmienená vysokou latenciou, ktorá je pre CSA príznačná. Podl’a výskumov sa približne iba tretina obetí CSA v priebehu detstva so svojou skúsenost'ou vôbec niekomu zdôverí (pričom tie, ktoré sa zdôveria tak zvyčajne činia s istým časovým oneskorením) a nejakej autorite, resp. orgánom činným v trestnom konaní je oznámených menej než $10 \%$ prípadov CSA. ${ }^{12}$ Súčast'ou problematiky latencie je napokon i to, že závery plynúce z prešetrovania prípadov podozrení z CSA môžu a nemusia byt’ správne. Možnosti

6 LALOR, Kevin a Rosaleen McELVANEY. Overview of the nature and extent of child sexual abuse in Europe. In: Protecting children from sexual violence A comprehensive approach. Strasbourg: Council of Europe, 2011, s. 13-43. ISBN 978-92-871-7114-6.

7 Súbor otázok zameraných na nekontaktné formy CS A zahŕnal: 1) nútenie pozerat' sa na genitálie inej osoby, 2) nútenie vyzliect' sa a ukazovat' svoje genitálie inej osobe, 3) nútenie pozerat' sa na masturbujúcu osobu, 4) nútenie pozerat' porno, 5) nútenie k foteniu nahého tela, 6) nedobrovol'né šírenie intímnych záberov tela iným l’ud’om alebo ich zverejnenie na internete, 7) sexuálne obt'ažovanie verbálne tvárou v tvár alebo cez email či SMS, 8) sexuálne obt’ažovanie cez internet. Internet pritom zodpovedal za cca 23-29\% of nekontaktných foriem CSA.

8 KARKOSKOVA a ROPOVIK, op. cit., s. 2.

9 Pri longitudinálnom výskume sa tá istá skupina subjektov skúma opakovane, obyčajne v priebehu dlhšieho obdobia (niekol'ko mesiacov, rokov aj desat'roči).

10 LANDOLT, Markus A., Ulrich SCHNYDER, Thomas MAIER a Meichun MOHLER-KUO. The Harm of Contact and Non-Contact Sexual Abuse: Health-Related Quality of Life and Mental Health in a Population Sample of Swiss Adolescents. Psychotherapy and Psychosomatics, 2016, roč. 85, č. 5, s. 320-322. DOI: 10.1159/000446810; PAOLUCCI, Elizabeth Oddone, Mark L. GENUIS a Claudio VIOLATO. A Meta-Analysis of the Published Research on the Effects of Child Sexual Abuse. The Journal of Psychology, 2001, roč. 135, č. 1, s. 17-36. DOI: 10.1080/00223980109603677

11 PÉREZ-FUENTES, Gabriela, Mark OLFSON, Laura VILLEGAS, Carmen MORCILLO, Shuai WANG a Carlos BLANCO. Prevalence and Correlates of Child Sexual Abuse: A National Study. Comprehensive Psychiatry, 2013, roč. 54, č. 1, s. 16-27. DOI: 10.1016/j.comppsych.2012.05.010

12 PIPE, Margaret-Ellen, Michael E. LAMB, Yael ORBACH a Ann-Christin CEDERBORG. Child Sexual Abuse: Disclosure, Delay and Denial. New York: Routledge, Psychology Press, Taylor \& Francis Group, 2007, 328 s. ISBN 978-0805863178. 
a limity identifikácie prípadov CSA sú načrtnuté v schéme č. 1. Prvá úroveň identifikácie CSA obsahuje potenciál krivých obvinení (v schéme zvýraznené šedým rámčekom).

Schéma 1: Možnosti a limity identifikácie obetí CSA ${ }^{13}$

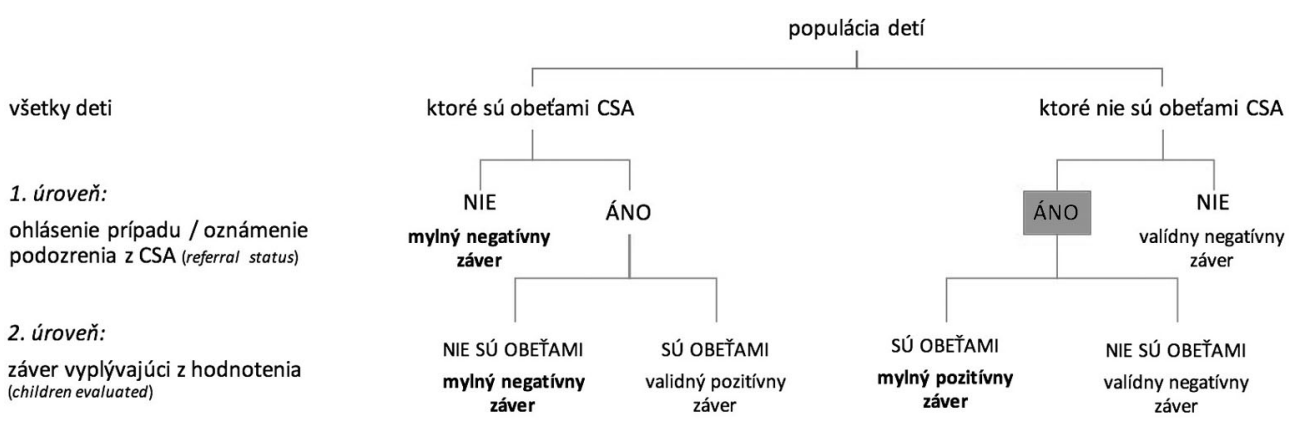

Berúc do úvahy skutočnost', že spomedzi prípadov podozrení z CSA, ktoré sa dostanú do pozornosti kompetentných orgánov, ${ }^{14}$ môže byt' čast' prípadov reálna a čast' taká, kde sa podozrenia nezakladajú na skutočnosti, uvedená schéma zachytáva štyri možné závery pri identifikovaní prípadov CSA, pričom dva závery sú správne a dva nesprávne: ${ }^{15}$

1. mylný negatívny záver (false negative): záver, že diet’a nebolo zneužívané pričom ale ono obet'ou je,

2. validný pozitívny záver (valid positive): záver, že diet'a bolo zneužívané pričom ono naozaj zneužívané bolo,

3. mylný pozitívny záver (false positive): záver, že diet’a bolo zneužívané hoci v skutočnosti ono obet'ou nie je,

4. validný negatívny záver (valid negative): záver, že diet’a nebolo zneužívané pričom ono vskutku nie je obet'ou.

13 Upravené podl'a: BRIDGES, Ana J., David FAUST a David C. AHERN. Methods for the Identification of Sexually Abused Children: Reframing the Clinician's Task and Recognizing Its Disparity with Research on Indicators. In: KUEHNLE Kathryn a Mary CONNELL (eds.). The evaluation of child sexual abuse allegations: a comprehensive guide to assessment and testimony. New Jersey: John Wiley \& Sons, Inc., 2009, s. 21-47. ISBN 978-0470288603.

14 Vôbec prvá štúdia, ktorá sa pokúšala zistit' výskyt nepravdivých podozrení z CSA, je štúdia fínskych vedcov. Analyzovali dva súbory dát: 1) dáta z reprezentatívnej štúdie na det'och vo veku 12-15 rokov a 2) dáta z reprezentatívnej štúdie na dospelých s priemerným vekom 34 rokov. Mylné podozrenia z CSA (teda, že sa o nich niekto mylne domnieval, že sú obet'ami CSA) uviedlo 1,5\% detských respondentov a 1,9 \% dospelých. Spomedzi mylných podozrení 14,5 \% (v prvej vzorke) a 9,1 \% (v druhej vzorke) bolo oznámených autoritám (orgánom sociálnoprávnej ochrany detí alebo polícii). (KORKMAN, Julia, Jan ANTFOLK, Monica FAGERLUND a Pekka SANTTILA. The prevalence of unfounded suspicions of child sexual abuse in Finland. Nordic Psychology, 2018. DOI: 10.1080/19012276.2018.1470554).

15 Existuje aj d'alší variant a síce, že v niektorých prípadoch vzhl’adom na nedostatok dôkazového materiálu, žiaden záver nie je možný (no judgment possible). Tento variant často implikuje uzavretie prípadu, a potenciálne necháva mnoho zranitel’ných detí bez ochrany pred neidentifikovanými páchatel'mi (MELKMAN, Eran P., Irit HERSHKOWITZ a Ronit ZUR. Credibility assessment in child sexual abuse investigations: A descriptive analysis. Child Abuse \& Neglect, 2017, roč. 67, č. 5, s. 76-85). 
Ktorýkol’vek chybný záver je vysoko nežiadúci, pretože v stávke je príliš vel’a - tak vo vzt'ahu k obetiam ako i páchatel’om. Mylne pozitívne závery ohl’adne CSA môžu viest' $\mathrm{k}$ trestnému stíhaniu nevinných osôb; $\mathrm{k}$ ich sociálnej stigmatizácii (prejavy nedôvery a morálneho odsúdenia zo strany sociálneho okolia); k narušeniu rodinných a iných blízkych vzt'ahov; $\mathrm{k}$ strate zamestnania; $\mathrm{k}$ finančným stratám; a/alebo k iným negatívnym následkom na kvalitu života dotknutej osoby a jej blízkych. ${ }^{16}$ Popri negatívnych následkoch dopadajúcich na údajných páchatel’ov CSA, môžu mylne pozitívne závery ohl'adne CSA viest' aj k narušeniu psychosociálneho vývoja údajných obetí a k d’alším negatívnym následkom na strane zainteresovaných inštitúcií (orgány činné v trestnom konaní, orgány sociálnoprávnej ochrany, súdni znalci, atd’. ${ }^{17} \mathrm{Na}$ druhej strane mylne negatívne závery môžu narúšat' alebo blokovat' prístup obetí k primeranej starostlivosti a ochrane; môžu aktuálne a potenciálne obete páchatel'a vystavit' riziku d’alšieho zneužívania v budúcnosti; môžu prispiet' k rozvoju celého spektra dlhodobých negatívnych následkov na život obetí CSA (vrátane narušenia sociálnych vzt'ahov a sociálnej stigmatizácie); nevymožitel'nost' práva môže byt' sama o sebe zdrojom psychického utrpenia, atd'. ${ }^{18}$

Z právneho hladiska možno hovorit’ o štyroch možných výsledkoch právneho posúdenia predmetných prípadov (ktoré sú načrtnuté v schéme č. 2). V rámci nich existuje riziko dvojakého typu justičného omylu, definovaného ako nedosiahnutie požadovaného konečného produktu spravodlivosti. ${ }^{19}$ Pri jednom type justičného omylu nevinná osoba môže byt' neoprávnené zadržaná, zatknutá, obžalovaná, odsúdená, podrobená trestnej sankcii, zatial’ čo pri druhom type justičného omylu u vinnej osoby nedôjde k zatknutiu, náležitému vyšetrovaniu, vzneseniu obžaloby alebo je vinná osoba oslobodená spod obžaloby čím dochádza k nesmiernym krivdám vo vzt'ahu k skutočným obetiam. ${ }^{20}$

16 BRADLEY, April R., John-Paul LEGERSKI, Katie THOMAS a Kristin E. MATSON. Truth, Lies, and Recantation. In: O'DONOHUE, William T. a Matthew FANETTI (eds.). Forensic Interviews Regarding Child Sexual Abuse: A Guide to Evidence-Based Practice. Cham, Switzerland: Springer International Publishing, 2016, s. 293-305. ISBN 978-3-319-21097-1; MELKMAN et al., op. cit., s. 76-85.

17 ČÍRTKOVÁ, Ludmila. Když se zneužívá sexuální zneužívání. Právo a rodina, 2017, roč. 19, č. 1, s. 1-8.

18 BOLEN, Rebecca Morris. Child Sexual Abuse: Its Scope and Our Failure. New York: Kluwer Academic Publishers, 2001, 306 s., s. 229. ISBN 0-306-46576-0; STALLER, Karen M. a Frank E. VANDERVORT. Child sexual abuse: legal burdens and scientific methods. In: STALLER, Karen M. a Kathleen COULBORN FALLER (eds.). Seeking Justice in Child Sexual Abuse: Shifting Burdens and Sharing Responsibilities. New York: Columbia University Press, 2010, s. 1-32. ISBN 978-0231146142; BRADLEY et al., op. cit, s. 293-305; MELKMAN et al., op. cit., s. 76-85.

19 KASINEC, Rudolf. Alternatívne tresty ako brzda justičných omylov. In: STRÉMY, Tomáš (ed.). Restorativna justicia a systém alternativnych trestov. Zbornik z medzinárodnej vedeckej konferencie. Praha: Leges, 2017, s. 320-329. ISBN 978-80-7502-224-0.

20 TURVEY, Brent E. a Craig M. COOLEY. Miscarriages of Justice: Actual Innocence, Forensic Evidence, and the Law. Oxford: Academic Press, 2014, 416 s., s. 6. ISBN 9780124115583; KASINEC, op. cit., s. 325; STALLER a VANDERVORT, op. cit., s. 1-32. 
Schéma 2: Právne posúdenie osoby podozrivej zo spáchania CSA ${ }^{21}$

\begin{tabular}{lccc}
\hline & & Faktický stav & N e v i n n ý \\
\hline V i n n ý & Správny výsledok: uznaný vinným & $\begin{array}{c}\text { Nesprávny výsledok: falošné priznanie alebo } \\
\text { chybné usvedčenie (wrongful conviction) }\end{array}$ \\
\cline { 2 - 4 } $\begin{array}{l}\text { Právny } \\
\text { stav }\end{array}$ & V i n ný & $\begin{array}{c}\text { Nesprávny výsledok: neoprávnené } \\
\text { prepustenie (wrongful release) }\end{array}$ & Správny výsledok: uznaný nevinným \\
\hline
\end{tabular}

Riziko mylného trestnoprávneho výsledku (legal outcome) je v mnohých prípadoch CSA podmienené nedostatkom dôkazov, ktorými by sa bez rozumných a dôvodných pochybností (beyond reasonable doubt) preukázalo, že skutok sa stal, že je trestným činom a že ho spáchala konkrétna osoba. ${ }^{22}$ Okrem toho, na spôsob a výsledok vyšetrovania prípadov podozrení z CSA môže mat' vplyv rozličná úroveň vedomostnej výbavy zainteresovaných profesionálov, ich psychologické odlišnosti a také osobnostné premenné, ako sú presvedčenia o frekvencii výskytu krivých obvinení alebo dokonca sexizmus. ${ }^{23}$ Pri identifikácii CSA môže dôjst' k zlyhaniam aj kvôli tomu, ako je CSA definované v trestnom hmotnom práve a ako sú procesne regulované postupy pri vyšetrovaní (napr. aký profesionál je oprávnený viest' výsluch; či prípady posudzuje jednotlivec alebo multidisciplinárny tím). ${ }^{24}$

Kým bude $\mathrm{v}$ trestnom konaní prítomný l’udský faktor, nedokážeme možnost' vzniku omylu celkom vylúčit'. ${ }^{25}$ Minimalizácia výskytu mylných pozitívnych záverov (false positives) a mylných negatívnych záverov CSA (false negatives) je predmetom multidisciplinárneho vedeckého záujmu. Zatial’ však veda vie málo o tom, z čoho pozostávajú najlepšie postupy, ktoré by zabránili týmto chybám. ${ }^{26} \mathrm{~V}$ literatúre sa objavujú iba prvotné pokusy o teoretické rozpracovanie faktorov, ktoré treba preskúmat', aby sme lepšie porozumeli (potenciálne nepravdivým) obvineniam z CSA. ${ }^{27}$ (Prierez teoretickým konceptom potenciálne nepravdivých obvinení z CSA ponúka kap. 2.2 tejto štúdie).

21 STALLER a VANDERVORT, op. cit., s. 1-32.

22 Uvedené súvisí so zásadou „in dubio pro reo” (v pochybnostiach v prospech obvineného). V neistých prípadoch právny systém preferuje, aby radšej vinný odišiel slobodný než by mal byt' nevinný pozbavený slobody (STALLER a VANDERVORT, op. cit., s. 2).

23 O'DONOHUE, William T., Olga CIRLUGEA, Natalie BENNETT a Lorraine T. BENUTO. Psychological and Investigative Pathways to Untrue Allegations of Child Sexual Abuse. In: O'DONOHUE, William T. a Matthew FANETTI (eds.). Forensic Interviews Regarding Child Sexual Abuse: A Guide to Evidence-Based Practice. Cham, Switzerland: Springer International Publishing, 2016, s. 257-273. ISBN 978-3-319-21097-1.

24 Ibid, s. 257.

25 KASINEC, op. cit., s. 320.

26 O’DONOHUE et al., op. cit., s. 258.

27 Ibid, s. 258. 


\section{Krivé obvinenia ako predmet záujmu práva a multidisciplinárneho výskumu}

\subsection{Nepodložené a nepravdivé obvinenia nie sú synonymom krivých obvinení}

V právnom zmysle ${ }^{28}$ je krivé obvinenie vymedzené ako lživé obvinenie iného z trestného činu v úmysle privodit' jeho trestné stíhanie. Vo výklade tohto paragrafu trestného zákona sa uvádza, že ,ľ̌ivé obvinenie je vedomé nepravdivé oznámenie skutkových okolností, najmä kedy, ako a kde mal byt' trestný čin spáchaný a k.to je jeho páchatel’om. Objektivna stránka tohto trestného činu spočiva v nepravdivom obvineni konk rétnej nevinnej osoby (...) ro spáchania určitého trestného činu. Spravidla bude také obvinenie vo forme trestného oznámenia smerovaného orgánu čnnému $v$ trestnom konani (...). Pre vyvodenie trestnej zodpovednosti páchatel'a sa pri subjektivnej stránke vy̌̌aduje úmyselné qavinenie. Z hl'adiska subjektivnej stránky musi páchatel' chciet' alebo si byt' aspon vedomý toho, že inébo ľ̌ivo obviňuje z. trestnébo činu, a byt's tým uzrozumený a súčasne chciet alebo byt'

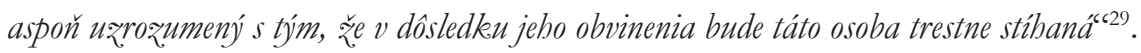

Z relevantnej judikatúry (napr. R 44/1965) vyplýva, že ak niekto iného lživo obvinil z konania, ktoré nezakladá zákonné znaky niektorého trestného činu, nespácha trestný čin krivého obvinenia; rovnako aj vyslovenie iba podozrenia, že niekto spáchal trestný čin, nemožno považovat' za vedome lživé, a teda krivé obvinenie. Z judikatúry Európskeho súdu pre l'udské práva (ESLP) vyplýva, že upozornenie na zneužívanie diet'at'a, ktoré bolo bona fide, by nemalo byt' kvalifikované ako trestný čin. V tomto ohl'ade pokial' ide o protichodné záujmy, ktoré boli v hre, ESL’P zdôraznil význam, aký má predchádzanie zneužívaniu diet'at'a (rozsudok ESL'P z 2. decembra 2008, Juppala proti Finsku). ${ }^{30}$

28 Zákon č. 300/2005 Z. z. Trestný zákon, \345.

29 BURDA, Eduard, Jozef ČENTÉŠ, Juraj KOLESÁR, Jozef ZÁHORA, J. et al. Trestný qákon. Osobitná čast'. Komentár. II. diel. 1. vyd. Praha: C. H. Beck. 2011, 1616 s. ISBN 9788074003943.

30 Z článku 19 Dohovoru o právach diet'at'a vyplývajú zmluvným štátom pozitívne záväzky prijat' všetky potrebné zákonodarné, správne, sociálne a výchovné opatrenia na ochranu detí pred akýmkol'vek násilím, vrátane sexuálneho zneuživania. „Tieto ochranné opatrenia zabrinajú podl’a potreby účinné postupy na vytvorenie sociálnych programov zameraných na poskytnutie nevyhnutnej podpory diet'at'u a tým, ktorým sa zverilo, ako aj iné formy prevencie. Na účly zistenia, oznámenia, postúpenia, vyšetrovania, liečenia a následné sledovanie uvedených prípadov zlébo zaobchádzania s det'mi zabrnajú takisto podla potreby postupy pre zásaby súdnych orgánov" (Dohovor o právach diet’at’a. Prijatý Valným zhromaždením OSN v New Yorku, 20 novembra 1989). Česká a Slovenská Federatívna Republiku Dohovor ratifikovala 7. januára 1991, platnost’ nadobudol dňom 6. februára 1991. - Podobné pozitivne záväzky vyvodil ESL’P vo svojej judikatúre z článku 3 (zákaz ponižujúceho zaobchádzania) a 8 (právo na súkromie) Dohovoru o ochrane luudských práv a základných slobôd. Česká a Slovenská Federatívna republika tento Dohovor ratifikovala 18. marca 1992, platnost' nadobudol v ten istý deň. Štát je podl'a ESL'P povinný zabezpečit' inter alia ochranu diet'at'a pred zneužitím. K porušeniu Dohovoru preto dochádza ak sociálni pracovníci alebo štátne orgány vedeli alebo mali vediet' o tom, že obet' bola vo vážnom ohrození a neurobili potrebné kroky, aby predišli porušeniu práv (pozri napríklad rozsudok z 23. septembra 1998, A. proti Spojenému Královstvu). V rozsudku z 26. novembra 2002, E. a d'alši proti Spojenému Královstvu, ESL'P vytvoril štandard pre porušenie práv diet'at'a z dôvodu zlyhania zabránit' sexuálnemu zneužitiu, ktorý sa aplikuje na sociálnych pracovníkov. 
V tejto súvislosti treba podotknút', že Slovenská republika ratifikovala tzv. Lanzarotský dohovor ${ }^{31}$, ktorý zaväzuje zmluvné strany k prijatiu takých legislatívnych a iných opatrení, ktoré by povzbudili každú osobu majúcu vedomost’ alebo podozrenie, v dobrej viere, o sexuálnom vykorist'ovaní alebo sexuálnom zneužívaní detí, aby oznámila tieto skutočnosti príslušným úradom. ${ }^{32} \mathrm{~V}$ rovnakom zmysle sa o oznamovaní poznatkov alebo dôvodných podozrení zo spáchania trestných činov súvisiacich so sexuálnym zneužívaním vyjadruje v článku 16 aj Smernica Európskeho parlamentu a Rady 2011/93/EÚ. ${ }^{33}$

Ak sa niekto hodnoverným spôsobom dozvie, že iný pripravuje, pácha alebo spáchal zločin, za ktorý trestný zákon ustanovuje trest odňatia slobody s hornou hranicou najmenej desat' rokov, a nesplní si oznamovaciu povinnost', takéto počínanie môže byt' samo o sebe trestné. ${ }^{34}$ Nie je podstatné, akým hodnoverným spôsobom sa niekto o trestnom čine dozvie, teda či vlastným poznatkom alebo z oznámenia obete či inej osoby. ${ }^{35,36}$ Je v kompetencii orgánov činných v trestnom konaní, aby podozrenie preverili. Oznamovatel’ nezodpovedá za to, ak sa aj neskôr pôvodné podozrenie nepreukáže.

Podl'a ESL'P k porušeniu pozitívnych povinností dochádza už vtedy, ak daný pracovník neuskutočnil dostupné primerané opatrenia, ktoré skutočne mohli zmenit’ alebo zmiernit’ spáchanú škodu. V rozsudku z 15. septembra 2009, E. S. a d'alši proti Slovenskej republike, ESL'P rozšíril túto zodpovednost' nielen na nečinnost' individuálnych sociálnych pracovníkov, ale aj na procesy v rámci systému, ktoré viedli k neúčinnej ochrane. - Bližšie k predmetnej problematike pozri: PIROŠÍKOVÁ, Marica. Najzranitel'nejší poškodení z hl'adiska judikatúry Európskeho súdu pre l’udské práva. Zo súdnej praxe, 2015, č. 6, s. 247-253; ÚRAD KOMISÁRA PRE DETI. Problém: „Syndróm zavrbnutého rodiča“ [online]. 2017 [cit. 21.3. 2018]. Dostupné z: https://komisarpredeti.sk/problem-syndrom-zavrhnuteho-rodica/

31 Dohovor Rady Európy o ochrane deti pred sexuálnym vykoristovaním a sexuálnym żneuživaním. Lanzarote 25. 10. 2007 (Dňa 1. marca 2016 bola u generálneho tajomníka Rady Európy uložená ratifikačná listina k tzv. Lanzarotskému dohovoru. Slovenská republika sa tak v poradí ako 40. členská krajina Rady Európy prihlásila k hodnotám a záväzkom dokumentu posilňujúceho ochranu detí pred týmito formami násilia. Dohovor pre Slovenskú republiku nadobudol účinnost' 1. júla 2016).

32 Ibid, článok 12.

33 Smernica Európskeho parlamentu a Rady 2011/93/EÚ z 13. decembra 2011 o boji proti sexuálnemu zneužívaniu a sexuálnemu vykorist'ovaniu detí a proti detskej pornografii, ktorou sa nahrádza rámcové rozhodnutie Rady 2004/68/SVV.

34 Zákon č. 300/2005 Z. z. Trestný zákon, 』 340 a 341.

35 MITLÖHNER, Miroslav. Právní aspekty zneuživání dětí. In: Komerčni sexuálni zneuživáni dětí: Násilí na dètech. Praha: Humanitas-Profes, o. p. s., 2001, s. 22.

36 Pokial ide o poskytovatel'ov zdravotnej starostlivosti, títo sú povinní oznamovat' prípady podozrení: (a) podložené prítomnost'ou špecifických príznakov, (b) podložené prítomnost'ou nejednoznačných špecifických príznakov a anamnestických údajov podporených prítomnost'ou nešpecifických príznakov alebo (c) ak skutok oznámi diet’a samé alebo iná osoba v súvislosti s poskytovaním zdravotnej starostlivosti diet'at'u (Odborné usmernenie Ministerstva zdravotníctva Slovenskej republiky o postupe poskytovatel'ov zdravotnej starostlivosti pri oznamovaní prípadov podozrenia zo sexuálneho zneužívania osôb do osemnást' rokov. Vestník MZ SR, 2010, Čiastka 4-6). 
V tejto súvislosti treba dodat', že nepodložené (unsubstantiated) prípady nie sú ekvivalentom úmyselných krivých obvinení. ${ }^{37}$ Prípady môžu byt' nepodložené $\mathbf{z}$ dvoch odlišných dôvodov:

a) skutok sa sice stal, ale niet o ňom dostatok dôkazov alebo sú dôkaz̧y nesprávne interpretovanể. „CSA je totiž vel'mi privátny, dobre utajovaný zločin, zvyčajne zahŕnajúci iba páchatel'a a obet', bez akýchkol'vek svedkov. Verbálne odhalenie, učinené zo strany diet'at'a alebo dospelého, je typicky primárnym a často aj jediným dôkazom, že k zneužívaniu došlo; potvrdzujúce dôkazy, ktoré by indikovali, či diet’a bolo vskutku zneužívané, sú skôr výnimkou než normou“39. ${ }^{40}$ Jediným kritériom, ktoré môže s istotou zaručit', že k žiadnemu CSA nedošlo, je absencia príležitosti - teda, že páchatel’ nemal prístup k obeti, alebo že obet' nebola vystavená kontaktu s páchatel'om. ${ }^{41}$

b) skutok sa nestal, a teda ide o nepravdivé obvinenie (untrue allegation): Avšak aj ked' sa oznámenie podozrenia z CSA nezakladá na skutočnosti, nemožno ho automaticky považovat' za zlovol'né, krivé obvinenie. Situácie, kedy sa kvôli podozreniu z CSA do pozornosti úradov dostanú deti, ktoré reálne nie sú obet’ami CSA, môžu vzniknút' z rôznych dôvodov, pričom vedomé klamstvo je len jedným z nich (a nie je nutne spojené s úmyslom privodit' inej osobe trestné stíhanie).

37 FALLER, Kathleen Coulborn. Interviewing Children about Sexual Abuse: Controversies and Best Practice. New York: Oxford University Press, 2007b, 328 s., s. 193. ISBN 978-0195311778; BOLEN, op. cit., s. 229; BLACK, Fiona A., Robert D. SCHWEITZER a Frank T. VARGHESE. Allegations of child sexual abuse in family court cases: A qualitative analysis of psychiatric evidence. Psychiatry, Psychology and Law, 2012, roč. 19, č. 4, s. 482-496. DOI: 10.1080/13218719.2011.613905; WEISER, Dana A. Confronting Myths about Sexual Assault: A Feminist Analysis of the False Report Literature. Family Relations, 2017, roč. 66, č. 1, s. 46-60. DOI: 10.1111/fare.12235

38 HUSSEY, Jon M., Jane Marie MARSHALL, Diana J. ENGLISH, Elizabeth Dawes KNIGHT, Anna S. LAU, Howard DUBOWITZ a Jonathan B. KOTCH. Defining maltreatment according to substantiation: Distinction without a difference? Child Abuse \& Neglect, 2005, roč. 29, č. 5, s. 479-492; GOODMAN-DELAHUNTY, Jane, Natalie MARTSCHUK a Annie COSSINS. Programmatic Pretest-posttest Research to Reduce Jury Bias in Child Sexual Abuse Cases. Oñati Socio-legal Series, 2016, roč. 6, č. 2, s. 283-314; LYON, Thomas D., Stacia N. STOLZENBERG a Kelly McWILLIAMS. Wrongful acquittals of Child Sexual Abuse. Journal of Interpersonal Violence, 2017, roč. 32, č. 6, s. 805-825; STALLER a VANDERVORT, op. cit., s. 1-32.

39 PIPE et al., op. cit., s. 5.

40 Napr. medicínske dôkazy o CSA je nájdu približne len v $4 \%$ vyšetrovaných prípadov (BERENSON, Abbey B., Mariam R. CHACKO a Constance M. WIEMANN. A case-control study of anatomic changes resulting from sexual abuse. American Journal of Obstetrics and Gynecology, 2000, roč. 182, č. 4, s. 820834. DOI: 10.1016/S0002-9378(00)70331-0; HEGER, Astrid, Lynne TICSON, Oralia VELASQUEZ a Raphael BERNIER. Children referred for possible sexual abuse: Medical findings in 2384 children. Child Abuse \& Neglect, 2002, roč. 26, č. 6-7, s. 645-659) a to jednak kvôli faktoru času (CSA nebýva oznamované okamžite a teda fyzické dôkazy sa stihnú zahojit') a rôznorodosti foriem CSA (z ktorých mnohé nemusia zanechávat' žiadne fyzické stopy). Navyše, aj ked’ sú fyzické dôkazy prítomné, stále ešte môžu zostávat' nezodpovedané otázky typu, kto je páchatel', kde a kol'ko krát sa CSA stalo, atd'.

41 FALLER, 2007b, op. cit., s. 195-196. 


\subsection{Teoretický model ciest k nepravdivým obvineniam z CSA}

Autori O’Donohue et $\mathrm{al}^{42}$ teoreticky rozpracovali šest' psychologických a investigatívnych ciest potenciálne vedúcich $\mathrm{k}$ nepravdivým obvineniam (untrue allegation) z CSA: nesprávna interpretácia nesexuálnych udalostí alebo konfabulácia; problematický výsluch; patológia diet'at'a; patológia dospelého; sugestívne kontakty a klamstvo diet'at’a. Každá z týchto hypotéz by pri konkrétnych obvineniach z CSA mala byt' preskúmaná. ${ }^{43}$

\subsubsection{Nesprávna interpretácia nesexuálnych udalostí alebo konfabulácia}

'Tvrdenia o sexuálnom zneužívaní môžu deti produkovat', ak zažili udalosti, ktoré mohli byt' mylne pochopené ako sexuálne zneužívajúce. To ako deti kategorizujú svoju skúsenost ${ }^{34}$ závisí od celého radu faktorov, ale ich kognitívny vývin môže obmedzit' alebo skreslit' ich úsudok. Diet’a mohlo mat' napr. nočnú moru o zneužívaní a môže sa domnievat', že sa to stalo naozaj. Inou situáciou, ktorá môže viest' k dezinterpretácii neškodenej udalosti ako zneužívajúcej, je napr. situácia umývania diet'at’a zo strany dospelého, ktorá je u malých detí primeraná a zvyčajne nemá zneužívajúci charakter. Ale za určitých okolností môže vzniknút' podozrenie z CSA - napr. ak diet'a uvádza nezvyčajné okolnosti umývania (trebárs že dospelý, ktorý diet’a kúpal príliš vel’a času strávil umývaním genitálii). Deti taktiež hrávajú medzi sebou hry, zahŕňajúca dotyky alebo iné prvky, ktoré môžu ale nemusia indikovat' CSA. ${ }^{45}$

42 O’DONOHUE et al., op. cit., s. 257-273.

43 Burnett uvádza aj d’alší možný dôvod krivých obvinení, vzt'ahujúci sa na situácie, kedy sú suspektné obete už dospelé. Tvrdí, že tým dôvodom môže byt' terapentická a kultúrna klíma, ktorá presviedča l'udí, že príčiny ich problémov $\mathrm{v}$ dospelosti tkvejú $\mathrm{v}$ potlačených zážitkoch zneužívania z detstva a ktorá ich povzbudzuje, aby minulost' uzavreli tým, že údajných páchatel'ov udajú. Okrem toho tvrdí, že tak pre terapeutov ako aj pre právnikov je výhodné, ak sa verí tomu, že CSA spôsobuje obetiam posttraumatickú stresovú poruchu a celoživotné následky. - Tvrdenia citovaného autora sú viac než kontroverzné a v našich podmienkach sotva platné. Odborná literatúra zaoberajúca sa následkami CSA totiž rozoznáva, že následky sú rôznorodé a venuje sa aj fenoménu resiliencie (odolnosti) a posttraumatického rastu. Okrem toho terapeuti, ktorí sa venujú obetiam CSA, nezvyknú odporúčat' dospelým obetiam právne riešenia sexuálneho zneužívania z dávnej minulosti, z dôvodu vysokého rizika sekundárnej viktimizácie obetí. Advokáti preferujú skôr iné oblasti práva, než trestné právo, a len málo z nich sa venuje zastupovaniu práv obetí. (BURNET'T, Ros. Reducing the Incidence and Harms of Wrongful Allegations of Abuse. In: BURNETT, Ros (ed.). Wrongful Allegations of Sexual and Child Abuse. Oxford, UK: Oxford University Press, 2016, s. 282-296. ISBN 9780198723301).

44 Jeden z primárnych spôsobov usporiadania skúseností je ich kategorizácia, v rámci ktorej sú zážitkom s podobnými znakmi priradzované jednotiace pojmové označenia. Pochopenie toho, ako sú položky spojené (how items go together), je základom adaptačného konania a riešenia problémov. Kategorizácia je proces, ktorý zasahuje celé obdobie vývinu, počnúc najrannejším detstvom, a ktorý sa mení súbežne s tým, ako sa rozvíjajú poznatky diet'at'a a jeho kognitívne zručnosti (GELMAN, Susan A. a Meredith MEYER. Child categorization. WIREs Cognitive Science, 2011, roč. 2, č. 1, s. 95-105).

45 O’DONOHUE et al., op. cit., s. 262-263. 
Okrem dezinterpretácie nesexuálnych zážitkov ako sexuálnych, môže dôjst’ k inkorporovaniu udalostí vzt'ahujúcich sa na CSA do neutrálnych (nesexuálnych) zážitkov. Mylné

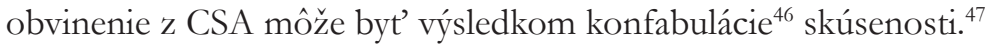

\subsubsection{Problematický výsluch}

K produkcii nepravdivých obvinení môžu prispiet' najmä štyri problematické techniky forenzného výsluchu: ${ }^{48}$

1. Kapciózne otázky. Teda ak osoba, ktorá vedie výsluch vnáša do rozhovoru a do formulácie otázok nové informácie, ktoré predtým diet’a neuviedlo.

2. Odvolávanie sa na výpoved' iných osôb ("other people” technique). Ak osoba, ktorá vedie výsluch informuje diet'a o tom, čo iní l’udia už o vyšetrovanej veci povedali (napr. že iné deti sa už o zneužívaní zdôverili), môže vytvárat' na diet'a tlak, aby vypovedalo v súlade s očakávaním (tlak na konformitu).

3. Selektívne posilňovanie určitých odpovedí diet'at'a. Posilňovanie je pojem zo sociálnej psychológie - ak za určitým správaním nasledujú pozitívne alebo negatívne konzekvencie (čiže odmeny a tresty) zvyšuje alebo znižuje to pravdepodobnost' výskytu určitého správania v budúcnosti. V kontexte výsluchu môže byt' táto technika použitá k ovplyvňovaniu odpovedí diet'at'a selektívnym odmeňovaním žiadúcich odpovedí a inhibovaním nežiadúcich odpovedí. Deje sa tak ak osoba, ktorá vedie výsluch: (a) pochváli diet’a alebo mu prisl'úbi odmenu (napr. si dobré dievča, na konci výsluchu dostaneš niečo sladké) len vtedy, ak diet’a dáva očakávané odpovede (napr. diet'a menuje osobu páchatel'a), a na druhej strane (b) prejavuje smútok, zamračenie, alebo reaguje spochybňujúco (si si istý, že sa to nestalo?) ak diet’a popiera zneužívanie.

4. Nepriame techniky výsluchu. Používanie rôznych pomôcok, ktoré vytvárajú priestor pre konštrukciu príbehu, zodpovedajúcu tomu, ako osoba, ktorá vedie výsluch interpretuje udalosti (za kontroverzné sa v tomto ohlade považuje aj používanie anatomických bábik pri výsluchu).

46 Konfabulácia je fenomén, pri ktorom je jedinec presvedčený, že určitá udalost' sa stala jemu, napriek tomu, že sa nikdy nestala, alebo sa stala inej osobe. Konfabulácia sa najčastejšie deje: (1) ak bola myšlienka na danú udalost' častá; (2) ak predstava konfabulovanej udalosti obsahuje vel'a detailov; (3) ak je udalost' l'ahko predstavitel'ná; (4) ak je emočná komponenta udalosti výraznejšia než „faktografická“ (PORUBANOVÁ, Michaela. Neuropsychologické hodnotenie pamäti [online]. 2012 [cit. 3. 3. 2018]. Dostupné z: https:// is.muni.cz/el/1423/podzim2012/PSY105/um/prednaska_RAVLT.pdf). - Deti môžu byt' pri rôznych príležitostiach vystavené sexuálnym obsahom - napr. preventívne programy v škole, informácie na internete, diskusia medzi det'mi, zdôverenie sa o CSA zo strany priatel'a alebo člena rodiny - a spracovanie takýchto informácií môže byt' za určitých okolností narušené a zosobnené (diet'at'om) (O’DONOHUE et al., op. cit., s. 262-263).

47 O'DONOHUE et al., op. cit., s. 262-263.

48 Ibid, s. 263-264. 
Medzi d'alšie techniky, ktoré môžu skresl'ovat' výpoved' (biasing techniques) diet'at'a možno zaradit' najmä to, ak osoba, ktorá vedie výsluch opomenie ubezpečit' diet'a o tom, že ak na nejakú otázku nebude vedie odpovedat', je v poriadku ak odpovie „neviem“; neprimerané používanie uzavretých otázok a neprimerané opakovanie otázok. ${ }^{49}$

K nepravdivým obvineniam môže prispiet’ aj nesprávna identifikácia sexuálneho groomingu. Grooming možno definovat' ako predchádzajúce nevhodné správanie (antecedent inappropriate behaviour), ktoré zvyšuje pravdepodobnost' budúceho sexuálneho zneužívania. Posúdenie groomingu by malo zahŕňat' dvojstupňový proces: (1) stanovenie, že správanie dospelého je samo osebe nevhodné; a (2) že možno oprávnene tvrdit', že funkciou tohto nevhodného správania je zvýšit' pravdepodobnost' budúceho zneužívajúceho kontaktu. Je možné, že nesprávne závery ohl’adne sexuálneho groomingu môžu viest' k nesprávnym záverom o pravdivosti obvinení z CSA. V kontexte výsluchu, ak diet'a uvádza, že mu podozrivá dospelá osoba v priebehu minulých mesiacov kupovala darčeky, vyšetrovatel' môže usúdit', že ide o sexuálny grooming a môže prejavit' zvýšenú tendenciu klást' diet'at'u otázky opierajúce sa o predpoklad, že k CSA vskutku došlo. - Obdobne sa môže stat', že rodič si všimne podozrivé správanie dospelého (ako napr. kupovanie darčekov diet'at'u) a opakovane sa bude diet'at'a predpojato dopytovat', či nedošlo k CSA. ${ }^{50}$

\subsubsection{Poruchy správania u detí a poruchy psychickébo vývinu}

O’Donohue et al. uvádzajú, že psychiatrické diagnózy u detí sú relatívne nepreskúmané z hl’adiska ich potenciálneho súvisu s nepravdivými obvineniami z CSA. Existujú psychiatrické diagnózy, ktoré sú spojené s náchylnost'ou diet'at'a klamat' a dokonca klamat' o dôležitých záležitostiach, ktoré môžu ublížit' druhým. ${ }^{51} \mathrm{~V}$ tomto ohl'ade sú relevantné najmä poruchy správania ${ }^{52}$. Ak anamnéza diet'at'a ukazuje dlhú históriu klamania a podvádzania, ktorá bola alebo môže byt' diagnostikovaná ako porucha správania, a dané diet'a vyjadruje obvinenie z CSA, je potrebné dôkladne zvážit', či sa nejedná o klamstvo

49 O’DONOHUE et al., op. cit., s. 263-264.

50 Ibid, s. 264-265.

51 Ibid, s. 266-268.

52 V MKCH-10 (Medżinárodná klasifikácia chorôb [online]. [cit. 12. 3. 2018]. Dostupné z: http://www.nczisk. sk/Standardy-v-zdravotnictve/Pages/Medzinarodna-klasifikacia-chorob-MKCH-10.aspx) sú označené diagnostickým kódom F91 a sú vymedzené nasledovne: „Poruchy správania charakterizuje opakované a pretrvávajúce, asociálne, agresívne alebo vyzývavé konanie. Také správanie môže vážne narušit’ veku primerané sociálne požiadavky. Ide teda o horšie počnanie, ako je obyčajné detské huncútstvo alebo pubertálna rebélia a má ráz trvalébo správania (aspoñ šest' mesiacov). Porucby správania mồzu byt' príznačné aj pre iné psychické choroby. V takých prípadoch treba uprednostnit' základnú diagnózu. Priklady správania, ktoré je podkladom pre diagnózu, zabrnajú nadmerné bitkárstvo a tyranizovanie, krutost' voči iným l'ud'om a zvieratám, t’ažké poškodzovanie majetku, podpal'ačstvo, krádeže, opakované klamanie, záśkoláctvo a utekanie z domu, nezvyčajne časté a vel'ké výbuchy zlosti a neposlušnost'. Spominané správanie, ak je dostatočne výrazné, postačuje na diagnózu, ale jednotlivé disociálne činy nestačia." 
a taktiež preskúmat', aký by na klamstve mohlo mat' diet'a záujem (teda či by ublížením údajnému páchatel’ovi mohlo niečo získat'). O’Donohue et al. v žiadnom prípade nechcú tvrdit', že diet'a, ktoré vykazuje vážne poruchy správania nemohlo byt' obet'ou CSA; podotýkajú, že v skutočnosti opak môže byt' pravdou, ked’že dôsledky CSA sa môžu manifestovat' aj v podobe behaviorálnych problémov. Autori iba upozorňujú na to, že deti s poruchami správania môžu mat' vyššiu tendenciu klamat' a preto netreba opomenút' potrebu preskúmat' hypotézu, že diet'a klame. ${ }^{53}$

Isté riziko nepravdivých obvinení z CSA môže byt' späté aj poruchami psychického vývinu suspektných obetí. Existujú nepochybné vedecké dôkazy o zvýšenom výskyte CSA v populácii duševne zaostalých (mentálne retardovaných) ${ }^{54}$ jedincov. Avšak ich problémy $\mathrm{v}$ oblasti spracovávania informácií môžu mat’ dva nežiadúce dôsledky: (1) môžu mat' tendenciu k zvýšenej sugestibilite a (2) môžu mat' väčšie t’ažkosti správne interpretovat' realitu. Ich chápanie toho, čo je dobrý dotyk alebo zlý dotyk, nemusí byt' tak presné ako u ich duševne nezaostávajúcich rovesníkov. Riziko produkcie nepravdivých obvinení z CSA je spájané aj s používaním nevhodných spôsobov výsluchu detî trpiacich pervazívnou vývinovou poruchou ${ }^{55}$, akou je napr. aj detský autizmus. ${ }^{56}$

\subsubsection{Patológia dospelého (rodiča, opatrovatel'a)}

Možným zdrojom nepravdivých obvinení z CSA môžu byt' aj psychózy. ${ }^{57}$ Psychotik môže trpiet' bludmi a halucináciami aj sexuálneho charakteru, vrátane obavy z toho, že niekto sexuálne ublíżil alebo ubližuje diet’at'u. Hoci je to vel'mi nepravdepodobné, za určitých

53 O’DONOHUE et al., op. cit., s. 266-268.

54 Podl’a MKCH-10 sa za mentálnu retardáciu (diagnostické kódy F70-F79) pokladá „Zastavenie alebo nedokončenie vývinu intelektu. Porucha sa prejavuje počas vývinovej periódy a charakterizuje ju najmä poškodenie schopností patriacich ke celkovej úrovni inteligencie, t.j. poznávacich, jazykeových, pobybových a sociálnych schopností. Retardácia sa vyskytuje s inými psychickými či somatickými poruchami alebo bez nich."

55 Podl’a MKCH-10 je pervazínna vývinová porucha (s diagnostickým kódom F84) „skupina porúch charakterizovaná kvalitatínnym z̧horšením recipročných sociálnych interakcii a spôsobov komunikácie a obmedżeným, stereotypným, opakujúcim sa repertoárom záujmov a aktivit. Tieto kvalitativne odchýlky sú prenikavou črtou fungovania jednotlivca vo všetkých situáciách."

56 O’DONOHUE et al., op. cit., s. 266-268.

57 Psychóza je všeobecný psychiatrický termín označujúci prejav t’ažkého duševného ochorenia, pri ktorom chorý stráca kontakt s realitou, ktorú inak vníma, inak ju hodnotí a inak sa preto správa. Táto strata kontaktu s realitou súvisí s bludmi (mylnými a spravidla nevyvrátitel’nými presvedčeniami) a halucináciami (klamnými vnemami, ktoré vznikajú nezávisle na vonkajšom podnete, ale chorý je nevyvrátitel’ne presvedčený o ich reálnosti). Pod ich vplyvom sa chorý môže dopúšt'at' pre okolie celkom nepochopitel’ných činov. Sám nemá na svoje ochorenie náhl’ad (Velký lékařský slovník [online]. 2018 [cit. 1. 4. 2018]. Dostupné z: http://lekarske.slovniky.cz/pojem/psychoza; VÁGNEROVÁ, Márie. Psychopatologie pro pomáhajíci profese. Praha: Portál, 2004, 872 s. ISBN 80-7178-802-3). Medzi najvážnejšie psychotické ochorenia patrí schizofrénia. 
okolností môže psychotik zdiel'aním svojich bludov a halucinácií diet'at'u spôsobit', že si ono dezinterpretuje vlastnú skúsenost'. ${ }^{58}$

O’Donohue et al. ${ }^{59}$ predpokladajú, že aj niektoré poruchy osobnosti môžu prispiet' k vzniku nepravdivých obvinení z CSA. Napr. pri disociálnej poruche osobnosti ${ }^{60}$ môžu l'udia bez ostychu klamat' a bezohl'adne obviňovat' iných. Podobne niektoré črty emočne nestabilnej poruchy osobnosti ${ }^{61}$ môžu disponovat' jedinca k pomstychtivému konaniu a k extrémnom $\mathrm{v}$ hodnotení druhých $\mathrm{v}$ interpersonálnych vzt'ahoch (striedanie idealizácie a znehodnocovania druhej osoby), ktoré môže potenciálne ovplyvňovat’ aj deti.

Napokon je pre vznik nepravdivých obvinení z CSA podl’a O’Donohue et al. do istej miery relevantná aj depresívna nálada, pod vplyvom ktorej môže dospelý vystavovat' diet'a svojej beznádeji a negatívnemu vnímania sveta. Vyjadrenia typu „nám sa vždy dejú zlé veci'“ môže diet'a pochopit’ tak, že aj jemu niekto ublížil, čím môže dôjst’ k vytvoreniu falošných spomienok. Hoci je takýto scenár málo pravdepodobný, poukazuje na dôležitost' porozumenia kontextu a faktorom, ktoré viedli k počiatočnému vysloveniu podozrenia (initial outcry) z CSA. ${ }^{62}$

\subsubsection{Sugestivne kontak.ty}

Okrem toho, že zdrojom sugestívnych vplyvov môžu byt' profesionáli, ktorí realizujú forenzný výsluch diet'at'a, môže sa stat', že rodičia alebo opatrovatelia diet'at'u podsunú zavádzajúce informácie. ${ }^{63}$ Za určitých okolností môžu sugestívne kontakty, ktorým bolo diet'a vystavené, prispiet' k nepravdivým obvineniam z CSA. Nie je to však tak jednoduché, ako by sa mohlo zdat'. Názor, že deti vo väčšej miere podliehajú sugesciám než

58 O’DONOHUE et al., op. cit., 268-270.

59 Ibid, s. 269-270.

60 Charakterizuje ju neuznávanie sociálnych záväzkov, nedostatok citov k iným. Všeobecne sa prejavuje rozpor medzi správaním a prijatými sociálnymi normami. Skúsenost' vrátane trestu sotva ovplyvňuje správanie. Nízka tolerancia frustrácie a nízky prah pre výbuchy agresie, vrátane násilia; tendencia obviňovat' iných, alebo ponúkat' prijatel’né vysvetlenie správania, ktoré privádza osobu do rozporu so spoločnost'ou. V MKCH-10 je označená diagnostickým kódom F60.2.

61 Charakterizuje ju náchylnost' konat' impulzívne a bez ohl'adu na následky; nálada je nevypočítatel'ná a vrtošivá. Sklon k výbuchom emócií, neschopnost' ovládat’ citové výbuchy. Náchylnost' k priečnemu správaniu a ku konfliktom s inými, najmä ak sa impulzívne konanie zmarí, alebo ak sa posudzuje. Rozlišujú sa dva typy: impulzívny typ charakterizovaný najmä citovou nestálost'ou a nedostatočným ovládaním impulzov a hraničný typ charakterizovaný navyše poruchami sebaobrazu, ciel'ov a osobných preferencií, intenzívnymi a nestabilnými medzil’udskými vzt’ahmi a tendenciou k sebadeštruktívnemu správaniu vrátane samovražedných gest a pokusov. V MKCH-10 je označená diagnostickým kódom F60.3).

62 O’DONOHUE et al., op. cit., s. 270.

63 O’DONOHUE et al., op. cit., s. 261-262. 
dospelí je súčasnými výskumníkmi zaoberajúcimi sa problematikou sugestibility, považovaný za zastaraný. ${ }^{64,65}$

Hoci mnoho l'udí si myslí, že je relatívne jednoduché niekomu cielene implantovat' do pamäte spomienky na udalosti, ktoré sa nikdy nestali (false memory), výskumné zistenia preukazujú, že opak je pravdou, a to aj pokial ide o deti. ${ }^{66}$ Vo všeobecnosti experimenty zamerané na falošné spomienky ukázali, že väčšina l’udí (70-85 \%) nie je náchylných na dezinformácie; a že dezinformačné efekty sa väčšinou vzt’ahujú na detaily, ktoré nie sú zvlášt' zapamätatel'né (not particularly memorable). ${ }^{67}$ Väčšina l'udí odoláva sugesciám, ktorým sú vystavení, napriek opakovaným pokusom o zapamätanie informácií, používaniu riadenej imaginácie, pozmeneným fotografiám alebo angažovanosti dôveryhodných dospelých. ${ }^{68}$ Deti už od troch rokov veku odmietnu nepravdivé sugescie, že boli zne-

64 BRAINERD, Charles J. Developmental reversals in false memory: A new look at the reliability of children's evidence. Current Directions in Psychological Science, 2013, roč. 22, č. 5, s. 335-341. DOI: 10.1177/0963721413484468; BRACKMANN, Nathalie, Henry OTGAAR, Melanie SAUERLAND a Marko JELICIC. When children are the least vulnerable to false memories: a true report or a case of autosuggestion? Journal of Forensic Sciences, 2016, roč. 61, č. S1, s. S271-S275. DOI: 10.1111/1556-4029.12926; HRITZ, Amelia Courtney, Caisa Elizabeth ROYER, Rebecca K. HELM, Kayla A. BURD, Karen OJEDA a Stephen J. CECI. Children's suggestibility research: Things to know before interviewing a child. Anuario de Psicología Jurídica, 2015, roč. 25, č. 1, s. 3-12; KIM, InKyeong, Enoch S. KWON a Stephen J. CECI. Developmental Reversals in Report Conformity: Psycho-legal Implications. Applied Cognitive Psychology, 2017, roč. 31, č. 2, s. 128-138. DOI: 10.1002/acp.3309; OTGAAR, Henry, Mark L. HOWE, Nathalie BRACKMANN a Daniel H. J. van HELVOORT. Eliminating Age Differences in Children's and Adults' Suggestibility and Memory Conformity Effects. Developmental Psychology, 2017, roč. 53, č. 5, s. 962-970. DOI: 10.1037/dev0000298; PETERSON, Dwight J., Kevin T. JONES, Jaclyn A. STEPHENS, Filiz GÖZENMAN a Marian E. BERRYHILL. Childhood Memory: An Update from the Cognitive Neuroscience Perspective. In: O'DONOHUE, William T. a Matthew FANETTI (eds.) Forensic Interviews Regarding Child Sexual Abuse: A Guide to Evidence-Based Practice. Cham: Springer, 2016, s. 81-105. ISBN 978-3-319-21097-1.

$65 \mathrm{~V}$ tomto ohl'ade viacerí autori upozorňujú na riziká plynúce z toho, že mnohí odborníci, vrátane súdnych znalcov, nie sú zorientovaní v súčasnom stave vedeckého poznania ohl’adne pamäte (BRACKMANN et al., op. cit., s. S271-S275; MELINDER, Annika a Svein MAGNUSSEN. Psychologists and psychiatrists serving as expert witnesses in court: what do they know about eyewitness memory? Psychology, Crime \& Law, 2015, roč. 21, č. 1, s. 53-61. DOI: 10.1080/1068316X.2014.915324; ZAJAC, Rachel, Maryanne GARRY, Kamala LONDON, Felicity GOODYEAR-SMITH a Harlene HAYNE. Misconceptions about childhood sexual abuse and child witnesses: implications for psychological experts in the courtroom. Memory, 2013, roč. 21, č. 5, s. 608-617. DOI: 10.1080/09658211.2013.778287).

66 BARLOW, M. Rose, Kathy PEZDEK, K. a Iris BLANDÓN-GITLIN, K. Trauma and Memory. In: GOLD, Steven N. (Ed.). APA handbooks in psychology. APA handbook of trauma psychology: Foundations in knowledge. Washington, DC, US: American Psychological Association, 2017, s. 307-331. ISBN 978-14338-2653-5; BREWIN, Chris R. a Bernice ANDREWS, B. Creating Memories for False Autobiographical Events in Childhood: A Systematic Review. Applied Cognitive Psychology, 2017, roč. 31, č. 1, s. $2-23$. DOI: 10.1002/acp.3220; PEZDEK, Kathy a Iris BLANDON-GITLIN. It Is Just Harder to Construct Memories for False Autobiographical Events. Applied Cognitive Psychology, 2017, roč. 31, č. 1, s. $42-44$. DOI: $10.1002 /$ acp.3269

67 BREWIN a ANDREWS, op. cit., s. 2-23; GOODMAN-DELAHUNTY, Jane, Mark Andrew NOLAN a Evianne L. van GIJN-GROSVENOR. Empirical guidance on the effects of child sexual abuse on memory and complainants' evidence. Sydney, Australia: Royal Commission into Institutional Responses to Child Sexual Abuse, 2017, 197 s. ISBN 978-1-925622-18-8.

68 BREWIN a ANDREWS, op. cit., s. 2-23. 
užívané. ${ }^{69}$ Ak by aj rodič navádzal diet'a na krivú výpoved', treba pamätat' na to, že diet'a pozná druhého rodiča. Výskumy preukázali, že deti menej podliehajú sugesciám o l’ud'och, ktorých dobre poznajú, a že sa zdráhajú obvinit’ z nemorálnych činov l’udí, ktorých l'úbia. ${ }^{70}$ Navyše v prípadoch, kde jedinci podl’ahnú sugesciám, neexistujú vedecké dôkazy, ktoré by preukázali, že falošné spomienky môžu byt' vytvorené s takým stupňom presvedčenia, aby ich bolo možné udržat' v priebehu dlhotrvajúcich súdnych konaní. ${ }^{11}$

\subsubsection{Diet'a klame}

V súvislosti s potenciálnym klamstvom u detí vo vzt'ahu k CSA, je dôležité roz̧išrovat', že a) deti môžu klamat' pri obviňovaní inej osoby z CSA alebo b) klamat' tým, že CSA popierajú. Vo vedeckej literatúre sa ovel'a častejšie objavuje znepokojenie z (frekventovanejšieho výskytu) varianty b) teda fenoménu popierania CSA. ${ }^{72}$

Za prípadným krivým obvinením môžu byt' rỗne motívy: ${ }^{73}$ pomsta niekomu kto diet'a nahneval; snaha vyvinit' sa z niečoho (napr. diet'a vyrukuje s obvinením vtedy, ak je potrestané za zlé správanie); snaha získat' pozornost' (napr. ak diet’a vypozorovalo, že iné diet'a ako obet' CSA bolo zahrnuté pozornost'ou a láskou rodičov); snaha vyhoviet' niekomu, kto krivým obvinením nejakej osoby sleduje vlastný záujem (napr. pomstu, finančný zisk). Preto je dôležité preskúmat' okolnosti za akých sa obvinenie z CSA objavilo.

Pokial' ide o klamstvo - musia byt' splnené dve kritéria aby sme mohli o klamstve vôbec hovorit': 1) diet'a uvádza nepravdu, 2) diet’a tak činí vedome. Uvedené je v priamom kontraste s fenoménom pamät'ovej chyby (alebo falošnej spomienky - false memory), pre ktorú je charakteristické, že diet’a uvádza nepravdu, ale zároveň verí (hoci nesprávne), že hovorí pravdu. ${ }^{74}$ Okrem toho treba brat’ do úvahy, že obvinenie z CSA je v skutočnosti sériou tvrdení týkajúcich sa toho kto, čo, kde, kol’ko krát spáchal, či pri

69 GOODMAN, Gail S., Bette L. BOTTOMS, Leslie RUDY, Suzanne L. DAVIS a Beth M. SCHWARTZ-KENNEY. Effects of past abuse experiences on children's eyewitness memory. Law and Human Behavior, 2001, roč. 25, č. 3, s. 269-298. DOI: 10.1023/A:1010797911805

70 LYON, Thomas D. New Wave in Children's Suggestibility Research: A Critique. Cornell Law Review, 1999, roč. 84, č. 4, s. 1004-1087; LYON, Thomas D. Let's not exaggerate the suggestibility of children. Court Review, 2001, roč. 38, č. 3, s. 12-14.

71 BREWIN a ANDREWS, op. cit., s. 2-23.

72 O'DONOHUE, William T. a Olga CIRLUGEA. How Often Do Children Lie About Being Sexually Abused? In: O'DONOHUE, William T. a Matthew FANETTI. Forensic Interviews Regarding Child Sexual Abuse: A Guide to Evidence-Based Practice. Cham, Switzerland: Springer International Publishing, 2016, s. 275-292. ISBN 978-3-319-21097-1; LYON, 1999, op. cit., s. 1004-1087; LYON, Thomas D. False Denials: Overcoming Methodological Biases in Abuse Disclosure Research. In: PIPE, Margaret-Ellen, Michael E. LAMB, Yael ORBACH. a Ann-Christin CEDERBORG (eds). Child Sexual Abuse: Disclosure, Delay and Denial. New York: Routledge 2007, s. 41-60. ISBN 978-0805852844.

73 O’DONOHUE a CIRLUGEA, op. cit., s. 275-292; O’DONOHUE et al., op. cit., s. 258-261.

74 Ibid. 
tom boli nejakí svedkovia, atd'. Niektoré z týchto tvrdení môžu byt' pravdivé, niektoré nie. 'Teda v konkrétnom prípade môže výpoved' diet'at'a obsahovat' kombináciu pravdivých a nepravdivých tvrdení. Otázka klamstva je teda vel'mi komplexnou otázkou. ${ }^{75}$

Aby profesionáli boli schopní robit' informované rozhodnutia o pravdepodobnosti pravdovravnosti v konkrétnom prípade podozrenia z CSA, je vhodné poznat' nejakú základnú mieru prevalencie klamstva. Pri hl’adaní serióznych údajov o tejto prevalencii je ale potrebné zohl'adňovat' vyššie naznačenú komplexnost' problematiky klamstva. Výskum, ktorý sa pokúša poskytnút' relevantnú odpoved' na otázku ako často deti klamú o CSA musí spĺňat' tri kritéria: (1) musí používat' metodológiu, ktorá by odôvodňovala záver, že tvrdenia diet'at'a sú vskutku nepravdivé; (2) musí používat' metodológiu, ktorá by dokázala posúdit’ či diet’a klame vedome; 3) tieto dve kritéria by sa za ideálnych okolností mali uplatnit' na každé sub-tvrdenie diet'at'a v jeho výpovedi. Splnenie týchto troch kritérií nie je l'ahké, a doterajší výskum (pozri kap. 2.3) v tomto ohl’ade má značné limity. ${ }^{76}$

\subsection{Zahraničné výskumy o výskyte krivých obvinení}

Nakol'ko podl'a nám dostupných informácií, na Slovensku dosial’ neboli realizované výskumy, ktoré by sa zameriavali na predmetnú problematiku, opierame sa v obsahu tejto subkapitoly o výsledky relevantných zahraničných výskumov. Ich prehlad načrtáva obraz o prevalencii krivých obvinení z CSA, spolu s metodologickými limitmi, príznačnými pre výskumy tohto typu.

Odborníci z odboru psychiatria a psychológia z Nového Mexika Goodwin et al. ${ }^{77}$ analyzovali 46 prípadov podozrení z CSA intrafamilárneho typu, s ktorými prišli do kontaktu pri svojej práci v rámci inštitúcie zameranej na ochranu detí (child abuse agency). Dospeli z záveru, že v skúmanej vzorke boli 2 prípady (4,3 \%) krivých obvinení zo strany psychotických matiek a 1 prípad (2,1\%) krivého obvinenia zo strany diet'at'a (išlo o 13 ročného chlapca, ktorý začal vykazovat' problémové správanie potom, čo sa jeho matka znovu vydala). Závery z tejto štúdie sú limitované tým, že nešlo o reprezentatívnu vzorku, a štúdia neobsahovala žiadnu metodológiu vzt’ahujúcu sa na posúdenie úmyslu (zlovol’nosti krivého obvinenia).

Jones a $\mathrm{McGraw}^{78}$ študovali spolu s tímom odborníkov podiel podložených (founded) a nepodložených prípadov CSA, na vzorke 576 prípadov, ktoré boli ohlásené oddeleniu sociálnych služieb v Denveri. Zistili, že 53 \% prípadov bolo podložených a zostávajúcich

75 O'DONOHUE a CIRLUGEA, op. cit., s. 275-292; O’DONOHUE et al., op. cit., s. 258-261.

76 O'DONOHUE a CIRLUGEA, op. cit., s. 275-292.

77 GOODWIN, Jean, Doris SAHD a Richard T. RADA. Incest hoax: False accusations, false denials. Bulletin of the American Academy of Psychiatry and the Law, 1978, roč. 6, č. 3, s. 269-276.

78 JONES, David P. H. a J. Melbourne McGRAW. Reliable and fictitious accounts of sexual abuse in children. Journal of Interpersonal Violence, 1987, roč. 2, č. 1, s. 27-45. DOI: 10.1177/088626087002001002 
$47 \%$ nie. Z toho najväčšia čast' (24\%) bola nepodložená kvôli nedostatočným informáciám. Ďalšia vel'ká kategória prípadov (17\%) boli nepodložené podozrenia (unsubstantiated suspicions). Iba $6 \%$ prípadov bolo klasifikovaných ako fiktívne (falošné). Z nich krivé obvinenia zo strany dospelých predstavovali $\mathbf{5} \%$ z celkového množstva prípadov, a krivé obvinenia zo strany detí $1 \%$. ${ }^{79}$ Po detailnej analýze fiktívnych prípadov CSA usúdili, že tieto charakterizujú také črty ako: nedostatok emócií, absencia vzorcov donútenia (coercion) alebo hrozby vo výpovedi o CSA či absencia detailov. Niektoré deti, ktoré podl'a nich uvádzali fiktívne CSA, trpeli v dôsledku skorších skúseností príznakmi postraumatickej stresovej poruchy (a spomienky na skoršie CSA si údajne zamieňali za prítomnú realitu); v niektorých prípadoch sa fiktívne obvinenie objavilo v kontexte poručenského sporu a niekedy bola za fiktívnym obvinením chabá kvalita forenzného výsluchu detí. Výskumníci zároveň priznali, že závery o krivých obvineniach na základe uvedených čŕt nemožno považovat' za absolútne. Výskumníci neposudzovali úmyselnost' nepravdivých obvinení z CSA a pri kategorizácii prípadov sa spoliehali na úsudok profesionálov. Výskumníci z University of North Carolina, Everson a Boat ${ }^{80}$ oslovili 100 pracovníkov z oblasti sociálno-právnej ochrany, z ktorých 88 sa do výskumu zapojilo. Títo prišli do kontaktu s 1249 prípadmi CSA. Podl'a ich odhadu boli deti pôvodcami krivých obvinení $\mathbf{v}$ priemere $\mathbf{v}$ 4,7 \% prípadoch, pričom výsledky poukazovali na rozdiely v odhade výskytu v závislosti od veku deti (deti do 3 rokov veku o CSA údaje klamali iba 1,6 \% prípadov, zatial’ čo deti nad 12 rokov už v $8 \%$ prípadov). V druhej fáze výskumu sa 24 z 34 profesionálov, ktorí uvádzali skúsenost' s prípadmi krivých obvinení, výskumníci pýtali na vysvetlenie ich úsudku. Ukázalo sa, že profesionáli svoje závery opierali o také kritéria ako: odvolanie výpovede, nedostatočné množstvo detailov vo výpovedi, nezrovnalosti vo výpovedi, absencia podporného medicínskeho nálezu, nedostatok strachu voči páchatel’ovi, alebo fakt, že páchatel' prešiel detektorom lži. Aj tento výskum mal viacero zásadných slabín. V prvom rade, validita väčšiny z uvádzaných kritérií podl’a súčasnej úrovne vedeckého poznania nepredstavuje spol'ahlivé indikátory falošných obvinení z CSA. Navyše nie je jasné kol'ko z tých kritérií malo byt' splnených ani akým spôsobom sa kombinovali pri posudzovaní jednotlivých prípadov. Autori opomenuli posudzovanie úmyslu diet'at'a (teda či išlo vedomé klamstvo) a vo výsledkoch sa spol’ahli len na subjektívny úsudok profesionálov.

79 Štúdiu autorov Jones a McGraw neskôr s drobnými metodologickými odlišnost’ami replikovali Oates et al., ktorí vo vzorke 551 Denverských prípadov podozrení z CSA ohlásených úradom sociálnoprávnej ochrany detí, zistili výskyt krivých obvinení zo strany detí na úrovni 1,5\% (OATES, Kim R., David P. H. JONES, David DENSON, Andrew SIROTNAK, Nancy GARY a Richard D. KRUGMAN. Erroneous concerns about child sexual abuse. Child Abuse \& Neglect, 2000, roč. 24, č. 1, s. 149-157. DOI: 10.1016/ S0145-2134(99)00108-8).

80 EVERSON, Mark D. a Barbara W. BOAT. False allegations of sexual abuse by children and adolescents. Journal of the American Academy of Child and Adolescent Psychiatry, 1989, roč. 28, č. 2, s. 230-235. DOI: 10.1097/00004583-198903000-00014. 
Američanka Kendall-Tackett ${ }^{81}$ oslovením 74 odborníkov s právnickým vzdelaním a 127 odborníkov v oblasti duševného zdravia zistila, že väčšina profesionálov sa domnievala, že deti o CSA klamú v menej ako 5 \% prípadov. Jej výskum mal ale viacero slabín: úmysel nebol posudzovaný (klamstvo nebolo odlíšené od pamät’ových chýb); použitá definícia klamstva nezahŕňala vedomé popieranie CSA (false denial); jedinou metódou na posúdenie výskytu krivých obvinení bol názor profesionálov bez uvedenia kritérií ako k rozhodnutiu dospeli a či použité kritéria boli vôbec správne.

Podl’a Kanadskej štúdie ${ }^{82}$ bolo z 12468 prípadov CSA 6244 nepodložených (unsubstantiated) pričom z nich $9 \%$ bolo považovaných za zlovol'né (malicious) krivé obvinenia. Z celkového počtu vyšetrovaných prípadov teda krivé obvinenia predstavujú 4,5 \%. Štúdia neuvádza kto bol považovaný za pôvodcu krivého obvinenia ani to, ako bola zlovol'nost' posúdená. Aj v tejto štúdii sa výsledky opierali len o subjektívny úsudok profesionálov podiel'ajúcich sa na vyšetrovaní prípadov.

V národnej Kanadskej štúdii Trocmé a Bala ${ }^{83}$ zist'ovali výskyt krivých obvinení vo vzorke 7672 prípadov (všetkých typov) zlého zaobchádzania s diet’at'om, ktoré sa dostali do pozornosti úradov pre sociálnoprávnu ochranu detí. Z nich podozrenia z CSA predstavovali 798 prípadov. Výskyt krivých obvinení z rôznych typov zlého zaobchádzania s diet'at'om dosahoval celkovo úroveň $4 \%$ a a kontexte poručenských sporov stúpol na $12 \% .{ }^{84}$ Krivé obvinenia z CSA sa vyskytli v $6 \%$ prípadov. Zo 43 krivých obvinení z CSA, žiadne nebolo vyslovené diet'at'om, 8 pochádzalo od rezidenčných rodičov, 7 od nerezidenčných rodičov, 6 zo strany príbuzných, susedov, či z okruhu známych; zvyšných 22 pochádzalo od iných alebo zo zdrojov, ktoré sa nedali identifikovat'. Výskumníci však vychádzali priamo z údajov a záverov, ktoré im dodali pracovníci úradov sociálnoprávnej ochrany detí. Títo, na základe vyhodnotenia dôkazov zhromaždených pri ich šetrení, kategorizovali prípady na podložené, podozrivé a nepodložené. Kategória nepodložených sa rozčleňovala ešte na prípady vnímané ako oznámenia podozrení s dobrým úmyslom a oznámenia, ktoré boli zámerne falošné (zlovol’né). Výsledky teda reprezentujú iba názory odborníkov ohl’adne úmyslu (intentionality) oznamovatel’ov.

81 KENDALL-TACKETT, Kathleen A. How many children make false allegations of sexual abuse?: A survey of mental health and law enforcement professionals. Family Violence Bulletin, 1991, roč. 7, č. 3, s. 19-21.

82 Public Health Agency of Canada, 2003 In: O’DONOHUE a CIRLUGEA, op. cit., s. 280-281.

83 TROCMÉ, Nico a Nicholas BALA. False allegations of abuse and neglect when parents separate. Child Abuse \& Neglect, 2005, roč. 29, č. 12, s. 1333-1345. DOI: 10.1016/j.chiabu.2004.06.016

84 Austrálski vedci Brown et al. analyzovali záznamy 149 náhodne vybraných prípadov poručenských sporov, $v$ ktorých sa objavili podozrenia z rôznych druhov násilia na det'och. Celkový výskyt krivých obvinení nepresiahol $9 \%$ (výskyt len vo vzt'ahu k CSA nebol posudzovaný samostatne). Kritéria pre krivé obvinenia neboli v štúdii špecifikované (BROWN, Thea, Margartia FREDERICO, Lesley HEWITT a Rosemary SHEEHAN. Revealing the Existence of Child Abuse in the Context of Marital Breakdown and Custody and Access Disputes. Child Abuse \& Neglect, 2000, roč. 24, č. 6, s. 849-859. DOI: 10.1016/ S0145-2134(00)00140-X). 
Niektoré štúdie sa zaoberali výskytom krivých obvinení z CSA špecificky v kontexte poručenských sporov o deti, nakol'ko sa v laických i odborných kruhoch rozmohlo presvedčenie, že ak sa pri súdnych t’ahaniach o deti objavujú podozrenia z CSA, väčšinou ide o krivé obvinenia. ${ }^{85}$ Štúdie, ktoré uvádzali vysoký výskyt krivých obvinení z CSA v kontexte poručenských sporov boli väčšinou kazuistického charakteru (teda prinášali popis pozorovaní prípadov z praxe autorov). ${ }^{86}$ Napr. Američania Benedek a Schetky ${ }^{87}$ z 18 prípadov údajného CSA, s ktorými sa stretli v psychiatrickej praxi pri posudzovaní poručenských otázok, 10 (56 \%) považovali za krivé obvinenia. Ich výsledky však musia byt’ interpretované opatrne, nakol'ko išlo o malú a vel'mi nereprezentatívnu vzorku prípadov. Navyše nešpecifikovali, či údajné krivé obvinenia pochádzali od detí alebo od dospelého. Napokon nie je známe či a aké kritéria použili na posúdenie úmyslu (zlovol’nosti krivých obvinenî).

Americký psychiater Green ${ }^{88}$ posudzoval 11 prípadov údajného CSA v kontexte poručenských sporov a usúdil, že 4 z 11 prípadov, t.j. 35 \% prípadov boli krivé obvinenia smerované proti otcom detí. Pre determinovanie, či bolo CSA fiktívne, použil nasledovné kritéria: prezradenie (disclosure) CSA je l’ahké a spontánne; prezradenie nie je sprevádzané negatívnymi afektmi; diet’a používa sexuálnu terminológiu dospelých; diet'a hovorí o CSA ked' získa ubezpečenie od matky; diet'a často konfrontuje otca s obvinením v prítomnosti matky; pozitívne interakcie medzi diet'at'om a otcom; paranoidná a hysterická matka, ktorá diet'a naviedla na krivé obvinenie; diet'a nevykazuje znaky a symptómy CSA. Nakol'ko väčšina Greenom použitých kritérií nebola potvrdená výskumom, jeho štúdia skvelo ilustruje riziká spoliehania sa na úsudok profesionála. Navyše je zjavné, že jeho výskumná vzorka nebola reprezentatívna.

Naproti kontroverzným štúdiám kauzistického charakteru, Faller a DeVoe ${ }^{89}$ z Michiganskej univerzity podrobne študovali 215 prípadov obvinení z CSA v rozvodových

85 Takéto tézy boli v nejednom prípade propagované autormi s propedofilnými názormi. V tomto ohl'ade pozri napr. informácie o autorovi Ralph Underwager, ktoré vo svojej kritickej štúdii uvádza: McDONALD, Merrilyn. The Myth of Epidemic False Allegations of Sexual Abuse in Divorce Cases. Court Review, 1998, roč. 35, č. 1, s. 12-19. Pozoruhodné sú aj informácie v kapitole o histórii vzniku a predstavitel'och nadácie tzv. syndrómu falošnej pamäte (False Memory Syndrome Foundation): ORR, Marjorie. False memory syndrome movements: the origins and the promoters. In: SINASON, Valerie (ed.). Memory in Dispute. New York: Routledge, 2018, s. 79-94. ISBN 978-1-85575-122-4. Zaujímavé sú aj ideové piliere kontroverznej teórie Richarda Gardnera o tzv. syndróme zavrbnutébo rodiča, sumarizované v dvojdielnej štúdii: KARKOŠKOVÁ, Slávka. Používanie konceptu „syndróm zavrhnutého rodiča“ v právnej praxi 1. čast'. Justičná revue, 2016, roč. 68, č. 6-7, s. 690-709; KARKOŠKOVÁ, Slávka. Používanie konceptu „syndróm zavrhnutého rodiča“" v právnej praxi - 2. čast’. Justičná revue, 2016, roč. 68, č. 8-9, s. 857-877.

86 Ako uvádza McDonald (1998), štúdie tohto typu nespĺňajú kritéria solídneho vedeckého výskumu (hard science), hoci môžu vzbudzovat’ dojem vedeckosti tým, že sú často citované.

87 BENEDEK, Elissa P. a Diane H. SCHETKY. Allegations of sexual abuse in child custody and visitation disputes. In: SCHETKY, Diane H. a Elissa P. BENEDEK (eds.). Emerging issues in child psychiatry and the law. New York, NY: Brunner/Mazel, 1985, s. 145-156. ISBN 978-0876303931.

88 GREEN, Arthur H. True and false allegations of sexual abuse in child custody disputes. Journal of the American Academy of Child Psychiatry, 1986, roč. 25, č. 4, s. 449-456. DOI: 10.1016/S0002-7138(10)60001-5

89 FALLER, Kathleen Coulborn a Ellen DeVOE, E. Allegations of sexual abuse in divorce. Journal of Child Sexual Abuse, 1995, roč. 4, č. 4, s. 1-25. DOI: 10.1300/J070v04n04_01. 
konaniach. Na základe analýzy dát z rozhovoru s diet'at'om, z rozhovoru s rodičom a klinického úsudku tímu odborníkov konštatovali, že $21 \%$ prípadov sa javilo ako falošných, ale väčšina neprávom obviňujúcich rodičov naozaj verila, že diet’a bolo viktimizované. Iba 10 prípadov, t.j. 4,7 \% bolo takých, kde rodičia vedeli, že podali krivé oznámenie (po konfrontácii sa ku krivému oznámeniu priznali). Pritom oných 10 krivých obvinení pochádzalo iba od 6 rodičov (4 krivé oznámenia podal jeden otec na jeho exmanželku, jej priatel’a, starú mamu a starého otca).

Aké závery vyplývajú z prehl’adu relevantných vedeckých štúdií? Kvôli metodologickým nedostatkom (limitom) existujúcich štúdií dospejeme k Sokratovskému záveru, že mieru prevalencie krivých obvinení z CSA nepoznáme. ${ }^{90}$ Doterajšie výskumy sa značne líšili v kritériách, ktoré používali na rozlíšenie opodstatnenosti podozrení a vyselektovanie krivých obvinení. Niektoré sa opierali o profesionálny úsudok a zvyčajne neuvádzali detaily týkajúce sa kritérií, na základe ktorých bol úsudok sformovaný; navyše nepreukázali do akej miery sa závery viacerých posudzovatel’ov zhodovali (interrater reliability). Iné štúdie používali varietu kritérií, z ktorých mnohé neboli empiricky potvrdené ako valídne indikátory krivých obvinení a navyše zvyčajne neuvádzali aká kombinácia kritérií viedla k výsledným záverom posúdenia. Žiadna štúdia neskúmala jednotlivé subkomponenty výpovede diet’at'a a dospelého, aby určila ktoré boli pravdivé a ktoré nie; všetky štúdie posudzovali tvrdenia o CSA ako celok. Avšak principiálnym metodologickým obmedzením doterajších výskumov je nedostatok valídnych metód na determinovanie či diet’a alebo dospelý uvádza nepravdu zámerne. Intencionalita je notoricky náročný konštrukt na to, aby ho správne posúdil vonkajší pozorovatel', preto vo vzt’ahu k oznamovaným podozreniam z CSA zostáva hádankou. Je zjavné, že deti a dospelí niekedy o CSA vedome klamú. Avšak neexistujú žiadne vedecké dôkazy nasvedčujúce tomu, žeby krivé (zlovol'né) obvinenia z CSA boli frekventovaným fenoménom, žeby tvorili väčšinu alebo čo i len značnú menšinu (sizable minority) spomedzi všetkých oznámených prípadov. ${ }^{91}$ Nízku mieru krivých obvinení z CSA uvádzajú viacerí experti zaoberajúci sa problematikou CSA. ${ }^{22} \mathrm{Na}$ získanie presnejšieho obrazu o výskyte krivých obvinení z CSA je potrebný d’alší výskum, s výskumnou metodológiu prekonávajúcu limity doterajších výskumov v tejto oblasti..$^{93}$

90 O'DONOHUE a CIRLUGEA, op. cit., s. 280-291; a O’DONOHUE et al., op. cit., s. 260-261.

91 Ibid.

92 SCHUMAN, Theresa M. Allegations of sexual abuse. In: STAHL, Philip M. (ed.). Complex issues in child custody evaluations. Thousand Oaks, CA: Sage, 1999, s. 43-68. ISBN 978-0761919094; BOLEN, op. cit., s. 109, 221; FALLER, 2007b, op. cit., s. 206; BROWNE, Kevin D. Assessing the Sexually Abused Child as a Witness. In: BROWNE, Kevin D., Anthony R. BEECH, Leam A. CRAIG a Shihning CHOU (eds.). Assessments in Forensic Practice: A Handbook. Chichester, West Sussex, UK; Malden, MA, USA: John Wiley \& Sons Ltd., 2017, s. 333-353. ISBN 9781118314531; MELKMAN et al., op. cit. 76-85; Podobne, vo vzt’ahu k sexuálnemu násiliu na ženách výskumné štúdie konzistentne uvádzajú mieru krivých obvinení pod hranicou $10 \%$ (WEISER, op. cit., s. 46-60).

$93 \mathrm{~V}$ nedávnej dobe sa objavila na trhu publikácia kolektívu autorov - BURNETT, Ros (ed.). Wrongful Allegations of Sexual and Child Abuse. Oxford, UK: Oxford University Press, 2016, 328 s. ISBN 9780198723301 - venovaná problematike krivých obvinení z CSA. Kým na jednej strane podotýka, 
Kým vedecký svet stále hl’adá spôsoby, ako sa čo najviac priblížit’ k poznaniu objektívnej skutočnosti, v každodennom živote tak laici ako i profesionáli vyslovujú svoje (neraz trúfalé a hrubo zjednodušené) odhady týkajúce sa výskytu krivých obvinení z CSA vo všeobecnosti alebo konštatovania vzt'ahujúce sa na konkrétne kauzy. O čo svoje odhady a konštatovania opierajú načrtne nasledujúca kapitola.

\section{Riziko predsudkov verzus reálne možnosti detekcie klamstva}

\subsection{Môže skúsenost' odborníkov z praxe prekonat' limity výskumu?}

Rovnaké problémy, ktoré limitujú výskum sa v ešte väčšej miere vzt'ahujú na situácie, kedy sa profesionáli pokúšajú identifikovat' rozlišujúce a validné indikátory krivých obvinení z CSA opierajúc sa o vlastnú skúsenost' z riešenia prípadov podozrení z CSA. ${ }^{94}$ Spoliehanie sa na profesionálnu skúsenost' (či už vlastnú alebo iných odborníkov) je vo všeobecnosti riskantné. Metaanalýzy štúdií, ktoré boli zamerané na skúmanie vzt'ahu medzi skúsenost'ou a správnost'ou klinického úsudku dospeli k záveru, že skúsenost' sama o sebe má na správnost' úsudku zanedbatel'ný vplyv. ${ }^{95}$ Výskumníci si zároveň všimli jeden nešt’astný dôsledok rozsiahlej praxe (skúsenosti) - a síce, že časom skúsení odborníci nadobúdajú stále väčší pocit istoty ohl'adne správnosti svojich úsudkov - a deje sa to bez toho, aby k skutočnému zlepšeniu správnosti úsudku naozaj dochádzalo. ${ }^{96}$

že akékol’vek pokusy posúdit’ prevalenciu krivých obvinení by boli značne špekulatívne, na druhej strane
tvrdí, že je pravdepodobné, že skutočná prevalencia krivých obvinení je omnoho vyššia než sa typicky
objavuje v diškurze o problematike zneuživania detí a znásilnenia. Kritické recenzie na túto publikáciu
(napr. SCORER, Richard. Book review: Wrongful allegations of sexual and child abuse. New Law Journal
[online]. [cit. 10.3.2017]. Dostupné z: https://www.newlawjournal.co.uk/content/book-review-wrong-
ful-allegations-sexual-and-child-abuse; PHOENIX, Jo. Wrongful Allegations of Sexual and Child Abuse.
By Ros Burnett (Oxford University Press, 2016). The British Journal of Criminology, 2017, roč. 57, č. 6,
s. 1527-1530) konštatujú, že ide o zbierku esejí z radov právnikov, vedcov, akademikov a žurnalistov,
pričom niektoré z nich sú síce dôležitým príspevkom k debate, ale v zásade zlyhávajú v ukotvení svojich
argumentov v literatúre a vedeckých dôkazoch a dokonca sa v nich objavujú aj nesprávne údaje (ill-infor-
med assertions). Najväčším prekvapením je, že publikácia nevenuje žiadnu pozornost’ základnej akademic-
kej otázke: ,ako vieme, že obvinenia sú nepravdivé?“ (PHOENIX, op. cit, s. 1527-1530).

94 BRIDGES et al., op. cit., s. 45.

95 SPENGLER, Paul M., Michael J. WHITE, Stefanía ÆGISDÓTTIR, Alan S. MAUGHERMAN, Linda A. ANDERSON, Robert S. COOK, Cassandra N. NICHOLS, Georgios K. LAMPROPOULOS, Blain S. WALKER, Genna R. COHEN a Jeffrey D. RUSH. The meta-analysis of clinical judgment project: Effects of experience on judgment accuracy. The Counseling Psychologist, 2009, roč. 37, č. 3, s. 350-399. DOI: 10.1177/0011000006295149; FAUST, David a Kyle A. FAUST. Experts' experience and diagnostic and predictive accuracy. In: FAUST, David (Ed.), Coping with psychiatric and psychological testimony: Based on the original work by Jay Ziskin (6th ed.). New York, NY: Oxford University Press, 2012, s. 131-146. ISBN 978-0195174113.

96 FAUST a FAUST, op. cit., s. 131-146; KORKMAN, Julia, Jatta SVANBÄCK, Katarina FINNILÄ a Pekka SANTTILA. Judges' views of child sexual abuse: Evaluating beliefs against research findings in a Finnish sample. Scandinavian Journal of Psychology, 2014, roč. 55, č. 5, s. 497-504. DOI: 10.1111/ sjop.12147; PELISOLI, Catula, Steve HERMAN, Debora Dalbosco DELL'AGLIO. Child sexual abuse research knowledge among child abuse professionals and laypersons. Child Abuse \& Neglect, 2015, roč. 40, c. 2, s. 36-47. DOI: 10.1016/j.chiabu.2014.08.010 


\section{Profesionálna skúsenost' s prípadmi CSA (dížka praxe) nie je sama o sebe zárukou} expertízy, pretože odborníci môžu byt' nositel'mi predsudkov a môže im chýbat' objektívna spätná väzba. ${ }^{97,98}$ Odborná skúsenost' sama o sebe neopraví mylné presvedčenia a nezvýši odbornost ${ }^{99}$, naopak s dĺžkou praxe môže zároveň narastat' aj utvrdzovanie sa v predpojatosti (resp. správnosti vlastného mylného presvedčenia) ${ }^{100}$.

V zahraničí je téme subjektivity a predpojatosti ${ }^{101}$ profesionálov vo vzt'ahu k problematike CSA venovaná značná výskumná pozornost’. Výskumníci preukázali, že profesionáli podiel'ajúci sa na riešení prípadov CSA sú nositel'mi mnohých mylných presvedčení, ktoré môžu ovplyvnit' vyšetrovanie a posudzovanie týchto prípadov. ${ }^{102,103}$ Napr. aj predsudky o obetiach CSA súvisiace s neznalost'ou tzv. kontraintuitívnych (counter-intuitive)

97 Zo skúsenosti je možné sa správne učit', iba ak jedinec pritom dostáva nepredpojatú a presnú spätnú väzbu na závery, ku ktorým dospel (DAWES, Robyn M., David FAUST a Paul E. MEEHL. Clinical versus actuarial judgment. Science, 1989, roč. 243, č. 4899, s. 1668-1674). Zakaždým, ked’ odborníci urobia chybu pri posudzovaní prípadov suspektných CSA, pravdepodobne o tom nevedia; a bez jasnej spätnej väzby o správnosti ich záverov, ako môžu použit’ svoju skúsenost' na zdokonalenie svojich rozhodnutî a metód? Odborník, ktorý tvrdí, že vd'aka skúsenostiam z praxe dokáže rozlíšit' medzi sexuálne zneužívanými det'mi a nezneužívanými det'mi, takmer určite zakladá svoje tvrdenie na dôkazoch s vážnymi nedostatkami a môže trpiet' falošnou sebaistotou (BRIDGES et al., op. cit., s. 45).

98 DAWES et al., op. cit., s. 1668-1674; GARB, Howard N. a William M. GROVE. On the merits of clinical judgment. American Psychologist, 2005, roč. 60, č. 6, s. 658-659. DOI: 10.1037/0003-066X.60.6.658; FINNILÄ-TUOHIMAA, Katarina, Pekka SANTTILA, Linda BJÖRNBERG, Niina HAKALA, Pekka NIEMI a Kenneth SANDNABBA. Attitudes related to child sexual abuse: Scale construction and explorative study among psychologists. Scandinavian Journal of Psychology, 2008, roč. 49, č. 4, s. 311-323. DOI: 10.1111/j.1467-9450.2008.00635.x; FINNILÄ-TUOHIMAA, Katarina, Pekka SANTTILA, Mikael SAINIO, Pekka NIEMI a Kenneth SANDNABBA. Expert judgment in cases of alleged child sexual abuse: Clinicians' sensitivity to suggestive influences, pre-existing beliefs and base rate estimates. Scandinavian Journal of Psychology, 2009, roč. 50, č. 2, s. 129-142. DOI: 10.1111/j.1467-9450.2008.00687.x; SPENGLER et al., op. cit., s. 350-399; BRIDGES et al., op. cit., s. 45; KORKMAN et al., op. cit., s. 497-504; PELISOLI et al., op. cit. 36-47.

99 FINNILÄ-TUOHIMAA et al., 2008, op. cit., s. 311-323.

100 PELISOLI et al., op. cit., s. 36-47.

$101 \mathrm{~V}$ tejto súvislosti sú relevantné viaceré pojmy, často používané ako synonymá: prekoncept - osobný názor, subjektívna koncepcia či teória opierajúca sa o intuíciu, individuálnu skúsenost', alebo aj o dezinformačné vplyvy (napr. z médiî); predsudok - skreslený názor o určitom jave nezohl’adňujúci dôkazy či overené informácie o danom jave; predpojatost' ( $\mathrm{z}$ ang. bias) - určitá tendencia, sklon, preferencia v uvažovaní, postojoch, zvyčajne založená na prekoncepte alebo neodôvodnená.

102 DAVEY, Robert I. a Jonathan HILL. A study of the variability of training and beliefs among professionals who interview children to investigate suspected sexual abuse. Child Abuse \& Neglect, 1995, roč. 19, č. 8, s. 993 942; FINNILÄ-TUOHIMAA, Katarina, Pekka SANT'TILA, Mikael SAINIO, Pekka NIEMI a Kenneth SANDNABBA. Connections between experience, beliefs, scientific knowledge, and self-evaluated expertise among investigators of child sexual abuse in Finland. Scandinavian Journal of Psychology, 2005, roč. 46, č. 1, s. 1-10. DOI: 10.1111/j.1467-9450.2005.00429.x; FINNILÄ-TUOHIMAA, Katarina. Expertise and decision making among clinicians in investigations of alleged child sexual abuse. Doctoral dissertation, Helsinki, Finland: Nordprint Oy, 2009, 120 s. ISBN 978-951-29-3894-0; KORKMAN et al. 2014, op. cit., s. 497-504; PELISOLI et al., op. cit., s. $36-47$.

103 Ak sú nositel'mi predsudkov napr. sudcovia, alebo ak si nevšimnú predpojatost’ iných odborníkov, ktorí sa na objasňovaní prípadov CSA podiel’ali, aj rozsudky môžu byt' náchylné na chyby (KORKMAN et al. 2014, op. cit., s. 497-504). 
reakcií obetí, môžu viest' $\mathrm{k}$ neadekvátnemu spochybňovaniu ich dôveryhodnosti ${ }^{104}$ a k záverom o tom, že dané prípady sú nepodložené a/alebo že ide o krivé obvinenia. ${ }^{105}$ Everson a Sandoval ${ }^{106}$ realizovali výskum predpojatosti na vzorke 1106 profesionálov pôsobiacich na rôznych pozíciách, $\mathrm{v}$ ktorých sa podiel'ali na foreznom posudzovaní suspektných prípadov CSA. ${ }^{107}$ Zistili, že rozpory posudzovatel'ov ohladne podozrení z CSA možno čiastočne vysvetlit’ individuálnymi rozdielmi vo výške skóre na škálach merajúcich tri postoje súvisiace s forenzným rozhodovaním:

1. dôraz na senzitivitu (emphasis-on sensitivity) - t.j. sústredenie sa na minimalizáciu výskytu mylne negatívnych záverov (false negative error), aby nedošlo k tomu, že skutočná obet' CSA bude neidentifikovaná a neposkytne sa jej starostlivost';

2. dôraz na špecifickost' (emphasis-on-specificity) - sústredenie sa na minimalizáciu mylne pozitívnych záverov (false positive error), aby nedošlo k tomu, že nevinná osoba bude odsúdená;

3. skepticizmus voči výpovedi detí - jedinci s vysokou mierou skepticizmu pristupujú k suspektným prípadom CSA s apriórnym presvedčením, že vysoké percento prípadov CSA je falošných. ${ }^{108}$

104 COSSINS, Anne. Prosecuting Child Sexual Assault Cases: Are vulnerable witness protections enough? Current Issues in Criminal Justice, 2006, roč. 18, č. 2, s. 299-317; FANFLIK, Patricia L. Victim Responses to Sexual Assault: Counterintuitive or Simply Adaptive? Alexandria, Virginia: American Prosecutors Research Institute, [online]. 2007, 36 s. [cit. 27.1.2018]. Dostupné z: http://www.ndaa.org/pdf/pub_victim_ responses_sexual_assault.pdf; Guidelines on Prosecuting Cases of Child Sexual Abuse [online]. London: The Crown Prosecution Service, 2013, rev. 2017. [cit. 21.3. 2018]. Dostupné z: http://www.cps.gov.uk/lega1/a_to_c/child_sexual_abuse/\#content; NATIONAL CRIME VICTIM LAW INSTITUTE. Victims' Rights Compel Action to Counteract Judges' and Juries' Common Misperceptions About Sexual Assault Victims' Behaviors. Violence Against Women Bulletin - Legalpublications project of The National Crime Victim Law Institute at Lewis \& Clark Law School. [online]. Portland Oregon, USA, 2014 [cit. 12. 3. 2018]. Dostupné z: https:/ / law.lclark.edu/live/files/17491-countering-common-misperceptions-of-sa-victims; Vysvetlenie kontraintuitívnych reakcií obetí CSA je v slovenskom jazyku dostupné v štúdii: KARKOŠKOVÁ, Slávka. Sexuálne zneužívanie detí: vzorce kontraintuitívnych reakcií obetí. In: HULLOVÁ, Monika (ed.). Zborník vedeckých štúdii a odborných článkov z. medzinárodnej virtuálnej vedeckej konferencie na tému Mravnostná kriminalita ako spoločenský fenomén a možnosti jej kontroly. Bratislava: Akadémia Policajného zboru, 2015, s. 190-205. ISBN 978-80-8054-647-2.

105 GOODMAN-DELAHUNTY et al., 2016, op. cit., s. 283-314; WEISER, op. cit., s. 46-60.

106 EVERSON, Mark D. a Jose M. SANDOVAL. Forensic child sexual abuse evaluations: Assessing subjectivity and bias in professional judgements. Child Abuse $\mho N$ Neglect, 2011, roč. 35, č. 4, s. 287-298. DOI: 10.1016/j.chiabu.2011.01.001.

107 Vo vzorke respondentov boli odborníci z oblasti sociálnoprávnej ochrany detí, odborníci na duševné zdravie, príslušníci orgánov činných v trestnom konaní, advokáti.

108 Autori poznamenávajú, že skepticižmus a dôraz na špecifickost' spolu súvisia, ale nie sú to synonymá. Jedinci, ktorí dosahujú vysoké skóre na škále skepticizmu s väčšou pravdepodobnost’ou pri rozhodovaní kladú dôraz na špecifickost'. Avšak opačne to nie vždy platí. Človek môže klást' značný dôraz na špecifickost' bez toho, aby bol predpojatý voči výpovedi detí o CSA. Podobne, zdôrazňovanie senzitivity oproti špecificite nevyžaduje presvedčenie, že všetky, alebo väčšina, prípadov CSA je pravdivá (EVERSON a SANDOVAL, op. cit., s. 287-298). 
Tieto postoje fungujú ako predsudky alebo predispozície vnímat' suspektné prípady CSA ako skôr pravdivé alebo skôr nepravdivé. ${ }^{109}$ Určenie toho, či v konkrétnom prípade diet’a (alebo dospelý) klame o CSA, je dôležitá ale náročná úloha, ktorej zvládnutie nepochybne komplikuje, ak má niekto apriórny postoj k predmetnej veci. ${ }^{110}$

Neistota (uncertainty) je nevyhnutným prvkom pri vyšetrovaní prípadov CSA a výskum týkajúci sa úsudkov a robenia rozhodnutí identifikoval viaceré problémy l’udského úsudku v situáciách neistoty, vrátane kognitívnych skreslení (cognitive bias), ${ }^{111,112}$ ktoré môžu viest' $\mathrm{k}$ selektívnemu zaobchádzaniu s informáciami, nedostatočnému kritickému mysleniu a opomenutiu zvážit' alternatívne pohl’ady. Zatial' čo správne by mali profesionáli pri vyhodnocovaní komplexných a neistých informácii (dôkazov) začínat' s úsudkom, ktorý sa opiera o základný odhad pravdepodobnosti (base rate probabilities) danej udalosti alebo javu a až následne tieto pravdepodobnosti upravit' na základe nových informáciî (tzv. Bayeziánsky prístup, z angl. Bayesian approach), často sa tak nedeje. ${ }^{113}$ Jedným z dôvodov je, že profesionáli nepoznajú relevantné výskumné údaje o miere výskytu určitých javov, napr. relevantné údaje o prevalencii CSA alebo o prevalencii krivých obvinení z CSA. Výskumy ukazujú, že za rozhodnutiami profesionálov často stoja kognitívne skreslenia, ${ }^{114}$ pričom v kontexte podozrení z CSA sú obzvlášt' relevantné tieto:

- konfirmačné skreslenie (confirmatory bias) - tendencia hl'adat', interpretovat', uprednostňovat' a vyvolávat' si z pamäti informácie takým spôsobom, ktorý potvrdí naše už existujúce presvedčenie alebo hypotézy, pričom sa venuje nepomerne menšia pozornost' alternatívnym možnostiam;

- heuristika dostupnosti (availability bias) - znamená, že pri rozhodovaní uprednostním informácie, ktoré si lahko vybavíme; vybavujeme si ich l’ahko na základe toho, že sa o nich často hovorí (pretriasajú sa napr. v médiách) a javia sa byt' rozšírenejšie než v skutočnosti sú. ${ }^{115}$

Na vytváraní presvedčení o vysokej miere krivých obvinení z CSA sa v nemalej miere podiel’ajú média, pre ktorých sú kauzy údajne krivých obvinení v poslednom období

\footnotetext{
109 EVERSON a SANDOVAL, op. cit., s. 287-298.

110 O'DONOHUE et al., op. cit., s. 259.

111 Kognitivne skereslenie je systematická, opakovaná chyba v myšlienkových procesoch (uvažovaní, rozhodovaní, odhadoch, spomienkach, zapamätávanî) pričom vyvodené závery o posudzovanej veci môžu byt' mylné.
}

112 FINNILÄ-TUOHIMAA et al., 2009, op. cit., s. 129-142.

113 FINNILÄ-TUOHIMAA et al., 2009, op. cit., s. 129-142.

114 FINNILÄ-TUOHIMAA et al., 2009, op. cit., s. 129-142; GAMBRILL, Eileen. Decision making in child welfare: Constraints and potentials. In: LINDSEY, Duncan a Aron SHLONSKY (Eds.), Child welfare research: Advances for practice and policy. New York: Oxford University Press, 2008, s. 175-193. ISBN 978-0195304961.

115 FINNILÄ-TUOHIMAA et al., 2008, op. cit., s. 311-323; KORKMAN et al., 2014, op. cit., s. 497-504. 
lákavou témou. ${ }^{116}$ Salter podotýka, že v súčasnom spoločenskom kontexte, ked’ vychádzajú na povrch d’alšie a d’alšie škandály týkajúce sa CSA, v niektorých oblastiach sa zároveň aj rozmáhajú stereotypy o obetiach zneužívania ako o pomstychtivých klamároch a vydieračoch. Dokonca došlo k sformovaniu aliancií medzi niektorými akademikmi a skupinami l'udí presadzujúcimi práva l’udí, ktorí sa stali údajne obet'ami krivých obvinení z CSA; čo vzbudzuje potrebu zvýšenej etickej kontroly (ethical scrutiny) a prezieravosti pri orientovaní sa v odbornej a vedeckej literatúre. ${ }^{117}$

Predpojatost' je súčast'ou l'udskej prirodzenosti a môže preniknút' aj do sveta vedy, pretože aj vedci sú len l'udia a môžu mat' svoje predsudky a taktiež odlišnú poznatkovú základňu ${ }^{118}$ a motívy. ${ }^{119}$ Aj ked' sa vo vede aplikujú viaceré metódy na redukovanie rôznych skreslení, k nežiadúcim skresleniam môže dôjst' aj tým, že sú výsledky štúdií nadmerne zovšeobecňované a aplikované na komplexné situácie, zahŕňajúce faktory, ktoré je náročné ak nie priam nemožné skúmat' v laboratórnych podmienkach. ${ }^{120}$ Určité skreslené pohl’ady (napr. zveličovanie problému sugestibility detí a potenciálu vytvorenia falošných spomienok) v minulosti ovplyvnili aj značnú čast' vedeckej literatúry, ktorá sa aplikovala aj na posudzovanie prípadov podozrení z CSA ${ }^{121}$ a sýtila tiež mediálny diškurz o údajne vysokom výskyte krivých obvinení z CSA. ${ }^{122} \mathrm{~K}$ tomuto diškurzu v nemalej miere v poslednom období prispieva aj pseudovedecká teória o tzv. syndróme zavr-

116 KITZINGER, Jenny. Framing abuse: Media influence and public understanding of sexual violence against children. London; Ann Arbor, MI: Pluto Press, 2004, 236 s., s. 54. ISBN 0-7453 23-31-6.

117 SALTER, Michael. Child sexual abuse. In: DEKESEREDY, Walter S. a Molly DRAGIEWICZ. Routledge Handbook of Critical Criminology. 2. vyd. London a New York: Routledge, 2018, s. 316-333. ISBN 9781138656192.

118 Napr. psychológovia zaoberajúci sa výskumom pamäte u detí ako svedkov (children's eyewitness memory) sa vo výskume spočiatku nešpecializovali na také témy ako CSA; emočné a sociálne vplyvy, ktoré prispievajú k mlčaniu detských obetí; alebo vplyv traumy na pamät'. Naproti tomu, výskumníci, ktorí sa v súčasnosti venujú výskumu pamäte u detí ako svedkov, sú už v týchto témach zbehlí (GOODMAN, Gail S., Olivia JONES a Cynthia McLEOD. Is There Consensus About Children's Memory and Suggestibility? Journal of Interpersonal Violence, 2017, roč. 32, č. 6, s. 926-939).

119 GOODMAN et al., 2017, op. cit., s. 926-939; RYDBERG, op. cit., s. 89-99.

120 GOODMAN et al., 2017, op. cit., s. 926-939.

121 SALTER, op. cit., s. 316-333; GOODMAN et al., 2017, op. cit., s. 926-939; ORR, op. cit., s. 79-94; RYDBERG, op. cit., s. 89-99.

$122 \mathrm{~V}$ tomto ohl'ade stoja za zmienku významné prípady údajne krivých obvinení z CSA, z obdobia 80-tych a 90-tych rokov minulého storočia. Tieto prípady boli laikmi a odborníkmi považované za moderný hon na čarodejnice pretože údajne $\mathrm{v}$ nich chýbali dôveryhodné dôkazy o CSA. Príbehy o bone na čarodejnice (Witch-Hunt Narrative) obsahovali aj extrémne tvrdenia o tom, že stovky prípadov boli vymyslené a stovky nevinných l'udí bolo odsúdených a uväznených. Dôkladná analýza prípadov ukázala, že v nich existujú dôveryhodné dôkazy o CSA, ktoré boli minimalizované alebo ignorované zo strany médií aj niektorých akademikov, ktorí zveličovali problém sugestibility detí (CHEIT, Ross E. The Witch-Hunt Narrative: Politics, Psychology, and the Sexual Abuse of Children. New York, NY: Oxford University Press, 2014, 532 s. ISBN 978-0190465575). To viedlo na jednej strane k mainstreemovej akceptácii presvedčenia o vysokom výskyte krivých obvinení a k spoločenskému podkopávaniu dôveryhodnosti výpovede detí; na druhej strane to zároveň prispelo k významnému progresu v postupoch výsluchu suspektných obetí CSA (LAMB, Nancy Beasley. The Witch-Hunt Narrative: Turning a Blind Eye to the Evidence in the So-Called Name of Justice. Journal of Interpersonal Violence, 2017, roč. 32, č. 6, s. 948-955; FALLER, Kathleen Coulborn. The Witch-Hunt Narrative: Introduction and Overview. Journal of Interpersonal Violence, 2017, roč. 32, č. 6, s. 784-804). 
hnutého rodiča, ktorá predpokladá, že podozrenia z CSA, ktoré sa objavia v kontexte rozvodu či rozchodu rodičovského páru sú spravidla účelové, slúžiace len ako nástroj pomsty a/alebo boja o diet’a. ${ }^{123}$ Nekritické osvojenie si premís tejto pseudovedeckej teórie u profesionálov prichádzajúcich do kontaktu so suspektnými prípadmi CSA, môže viest’ k mylne negatívnym záverom pri posudzovaní predmetných prípadov. ${ }^{124}$

\subsection{Intuícia verzus systematické metódy detekcie klamstva, resp. posudzovania vierohodnosti výpovede}

Intuitívne odhal'ovanie klamstva je značne nespol’ahlivé. Metaanalýza 45 experimentálnych výskumov zameraných na schopnost' l'udí rozlíšit' medzi pravdivými a nepravdivými výpoved’ami detí dospela k záverom, že tak laici ako aj profesionáli dosahujú v priemere len 54 \% mieru úspešnosti, teda úroveň len málo prekračujúcu hranicu náhody. ${ }^{125}$ Profesionáli sú pri detekovaní klamstva oproti laikom v priemere úspešnejší len v nepatrnej miere (56\% oproti 53,2\%). ${ }^{126,127}$

Za účelom zdokonalit' naše chabé schopnosti odhalit' klamstvo, resp. posúdit' vierohodnost' výpovede, boli navrhnuté mnohé vedecké (aj pseudovedecké) techniky hl'adajúce neverbálne, paraverbálne či fyziologické indikátory klamstva, no v posledných rokoch sa pozornost' sústredí na verbálne správanie, resp. na systematickú analýzu obsahu výpovede. ${ }^{128}$ Tento prístup je založený na Undeutschovej hypotéze, ${ }^{129}$ podl’a ktorej to, čo sme skutočne zažili, popisujeme inak ako to, čo si vymýšlame. ${ }^{130}$

123 KARKOŠKOVÁ, 2016a, op. cit., s. 690-709; KARKOŠKOVÁ, 2016b, op. cit., s. 857-877. K tejto problematike pozri napr. aj: Stanovisko Koalicie pre deti Slovensko ke reportáži o "syndróme zavrbnutébo rodiča" odvysielanej na Jednotke RTVS v relácii Reportéri [online]. 2017 [cit. 22. 3. 2018]. Dostupné z: http://koaliciapredeti. $\mathrm{sk} /$ press/stanovisko-koalicie-pre-deti-slovensko-k-reportazi-o-syndrome-zavrhnuteho-rodica-odvysielanej-na-jednotke-rtvs-v-relacii-reporteri/

124 FALLER, Kathleen Coulborn. Coaching children about sexual abuse: A pilot study of professionals' perceptions. Child Abuse \& Neglect, 2007a, roč. 31, č. 9, s. 947-959.

125 GONGOLA, Jennifer, Nicholas SCURICH a Jodi A. QUAS. Detecting deception in children: A meta-analysis. Law and Human Behavior, 2017, roč. 41, č. 1, s. 44-54. DOI: 10.1037/lhb0000211

126 Ibid.

127 Vrij, ktorý porovnal výsledky 79 štúdií, zistil, že profesionáli sú v porovnaní s laikmi síce viac sebaistí v detekovaní klamstva, ale iba nepatrne úspešnejší (55,9 \% oproti 54,3 \%) (VRIJ, Aldert. Detecting Lies and Deceit: Piffalls and Opportunities, Chichester: John Wiley \& Sons, 2008, 502 s. ISBN 978-0470516256).

128 AMADO, Bárbara G., Ramón ARCE a Francisca FARIÑA. Undeutsch hypothesis and Criteria Based Content Analysis: A meta-analytic review. The European Journal of Psychology Applied to Legal Context, 2015, roč. 7, č. 1, s. 3-12. DOI: 10.1016/j.ejpal.2014.11.002

129 UNDEUTSCH, Udo. The development of statement reality analysis. In: YUILLE, John C. (ed) Credibility assessment. Dordrecht; Boston: Kluwer Academic Publishers, 1989, s. 101-119. ISBN 978-0792301950.

130 Je to spôsobené odlišnost'ou psychických procesov, ktoré sa na vzniku výpovede podiel'ajú. Pri opisovaní autentických zážitkov hrá dominantnú úlohu epizodická (zážitková) pamät’ a ide teda o rekonštrukciu autentických zážitkov. Pri lživej výpovedi musí svedok aktivovat’ iné kognitívne procesy (napr. poznatky, predstavy), pretože ide o konštrukciu fiktívnych udalostí či príbehov. Klamár sa zvyčajne musí sústredit' na hlavný dej, nemá mentálny priestor pre vymýšllanie detailov či zvláštností, ani pre popisovanie vlastných emócií a myšlienok v udalosti, ktorú vykonštruoval (ČÍRTKOVÁ, Ludmila. Problematika posuzování věrohodnosti. Právo a rodina, 2018, roč. 20, č. 3, s. 12-17). 
Metóda SVA (Statement Validity Assessment), vyvinutá špeciálne na účely posudzovania vierohodnosti výpovedí detských obetí CSA (hoci neskôr sa jej používanie rozšírilo aj na dospelých a na iné kontexty než len CSA), pozostáva zo štyroch krokov: (1) analýzy spisu; (2) pološtruktúrovaného interview; (3) systematickej obsahovej analýzy výpovede (Criteria-Based Content Analysis - CBCA); a (4) hodnotenia výsledkov predošlého kroku s použitím setu otázok (Validity Checklist). Jadrom tejto metódy je tretí krok, v ktorom vyškolený odborník hodnotí v doslovnom prepise výpovede prítomnost' 19 kritérií, o ktorých sa predpokladá, že sa častejšie vyskytujú v pravdivých než v lživých výpovediach. ${ }^{131}$

Vo všeobecnosti, výpovede, ktoré sú koherentné a konzistentné (logická štruktúra); v ktorých nie sú informácie uvádzané v časovo chronologickom slede (neštruktúrovaná rečová produkcia); a ktoré obsahujú značné množstvo detailov (kvantita detailov), sú s väčšou pravdepodobnost'ou pravdivé. Z hl'adiska špecifického obsahu možné indikátory pravdivosti zahŕňajú zasadenie udalosti do časového a priestorového kontextu alebo ich prepojenie s inými dennými aktivitami a zvykmi; opis interakcií (čo, kto, kde na mieste činu robil); uvádzanie úryvkov dialógov, ktoré zazneli v priebehu činu; uvádzanie neočakávaných komplikácií, dejových zauzlení počas incidentu; uvádzanie nezvyčajných detailov týkajúcich sa l’udí, objektov alebo udalosti, ktoré sú jedinečné, nečakané, prekvapivé a v danom kontexte významné (napr. tetovanie páchatel’a); uvádzanie nadbytočných detailov, ktoré sa nevzt’ahujú k podstatným okolnostiam udalosti, ale dotvárajú príbeh; zmienka o detailoch, ktorým obet’ subjektívne nerozumie; uvádzanie detailov, ktoré nie sú súčast'ou vyšetrovaného činu ale súvisia s ním (napr. ak svedok popisuje, že páchatel’ pred činom hovoril o rôznych svojich sexuálnych zážitkoch); opis vlastného duševného stavu (emócií a myšlienok) v priebehu udalosti; interpretácia pocitov, myšlienok a motívov konania páchatel’a. Ďalšie kritéria sa s väčšou pravdepodobnost'ou objavujú v pravdivých výpovediach z dôvodov motivácie. Osoby hovoriace pravdu sa až tak nezaoberajú tým, aký dojem robia, zatial' čo klamári sa snažia kreovat' takú výpoved', o akej sa domnievajú, že na ostatných pôsobí dôveryhodným dojmom, a vynechat' to, o čom sa domnievajú, že by mohlo narušit' ich imidž úprimnosti. V dôsledku toho pravdivá výpoved' s väčšou pravdepodobnou obsahuje informácie, ktoré sú v rozpore so stereotypmi pravdivosti: spontánne opravy, spresnenia a doplnenia vo výpovedi; pripustenie, že niektoré veci osoba nevie alebo si ich nepamätá; vyjadrovanie pochybností o vlastnom svedectve (uvádzanie, že niektoré časti môžu vyznievat' zvláštne, nepravdepodobne, neuveritel'ne); sebakritika alebo sebaodsudzovanie vo vzt’ahu k niektorým okamihom vlastného počínania; ospravedlňovanie páchatel’a. Posledné kritérium sa vzt’ahuje na špecifiká trestného činu, ktorý je predmetom

131 VRIJ, Aldert a Giorgio GANIS. Theories in Deception and Lie Detection. In: RASKIN, David C., Charles R. HONTS, a John C. KIRCHER (eds). Credibility Assessment: Scientific Research and Applications, Kidlington, Oxford: Academic Press, 2014, s. 301-374. ISBN 978-0123944337. 
vyšetrovania - vierohodná výpoved' obsahuje opis prvkov, ktoré sú pre daný trestný čin typické, hoci sa môžu širokej verejnosti javit' ako kontraintuitívne. ${ }^{132}$

Pri analýze sa hodnotí prítomnost' alebo neprítomnost' uvedených kritérií, a v prípade prítomnosti aj ich stupeň. Predpokladá sa, že čím viac kritérií výpoved' diet'at'a spíňa (alebo čím sú kritéria výraznejšie prítomné), tým pravdepodobnejšie ide o spomienky, ktoré sú založené na reálne prežitých udalostiach. Avšak absencia kritérií nemôže byt' interpretovaná ako znak toho, že diet'a klame, ${ }^{133}$ pretože CBCA skóre môže byt' ovplyvnené inými faktormi, než je pravdivost' výpovede, ako sú napr.: ${ }^{134}$

- psychologické charakteristiky diet'at'a - napr. staršie deti produkujú výpovede, ktoré typicky obsahujú viac CBCA kritérií než výpovede mladších detí; diet’a si nemusí na udalosti v dostatočnej miere pamätat'; môže mat' narušenú kognitívnu kapacitu; nemusí byt' ochotné spolupracovat';

- kvalita výsluchu - schopnosti vypočúvajúceho môžu do vel'kej miery ovplyvnit' obsah a kvalitu výpovede diet'at'a; napr. ak vypočúvajúci nedal diet'at'u dostatok príležitosti, aby vypovedalo celý príbeh, potom bude výpoved' pravdepodobne obsahovat' menej CBCA kritérií; výpoved' môže byt' u vysoko sugestibilných detí skreslená, ak boli podrobené navádzajúcim otázkam.

$\mathrm{V}$ záverečnom kroku metódy SVA sa majú zvážit' rôzne alternatívne hypotézy pre CBCA skóre v posudzovanej výpovedi a tiež zohl’adnit' iné zdroje informácií (mimo výpovede), aby sa dospelo k stanovisku o vierohodnosti výpovede. ${ }^{135}$ Problémom tohto kroku je, že je náročné ak nie priam nemožné zistit’ či zmerat', aký presný vplyv mnohé faktory na CBCA skóre mali; a vzniká tak značný priestor pre subjektívne hodnotenia (závery posudzovatel'ov sa teda môžu rôznit'). ${ }^{136}$

Hoci sa SVA, a jej zložka CBCA, považuje za najrozpracovanejšiu a najviac používanú metódu na posudzovanie vierohodnosti výpovede, ${ }^{137,138}$ zároveň je vnímaná ako

132 VRIJ a GANIS, op. cit., s. 301-374; VRIJ, Aldert. Verbal Lie Detection Tools: Statement Validity Analysis, Reality Monitoring and Scientific Content Analysis. In: GRANHAG, Pär Anders, Aldert VRIJ, a Bruno VERSCHUERE (eds.). Detecting Deception: Current Challenges and Cognitive Approaches. 1. vyd. Chichester, West Sussex, UK: John Wiley \& Sons, Ltd., 2015, s. 3-35. ISBN 978-1118509753.

133 RASKIN, David C. a Phillip W. ESPLIN. Statement Validity Assessment: Interview procedures and content-analysis of children's statements of sexual abuse. Behavioral Assessment, 1991, roč. 13, č. 3, s. 265-291; AMADO et al., op. cit., s. 3-12.

134 VRIJ a GANIS, op. cit., s. 301-374; AMADO et al., op. cit., s. 3-12; CYR, Mireille a Guy BRUNEAU. False Allegations of Child Sexual Abuse [online]. INSPQ, Centre de expertise et de référence en santé publique. Gouvernement du Québec, 2012 [cit. 12.2.2018]. Dostupné z: https://www.inspq.qc.ca/en/ print/sexual-assault/fact-sheets/false-allegations-child-sexual-abuse

135 RASKIN a ESPLIN, op. cit., s. 265-291.

136 VRIJ a GANIS, op. cit., s. 301-374; AMADO et al., op. cit., s. 3-12.

137 AMADO et al., op. cit., s. 3-12.

138 SVA má pôvod vo Švédsku a Nemecku, a okrem týchto krajín sa používa v niektorých štátoch Severnej Ameriky, a v niektorých západoeurópskych krajinách (napr. Holandsko) (VRIJ a GANIS, op. cit., s. 301-374). V Anglicku, Kanade a USA nie je CBCA metóda prípustná ako valídny dôkaz pred súdom (AMADO et al., op. cit., s. 3-12). 
kontroverzná, ${ }^{139}$ nedostatočne validná a reliabilná. ${ }^{140}$ Z experimentálnych výskumov, ktoré overovali spol'ahlivost' CBCA kritérií v laboratórnych podmienkach vyplýva, že priemerná úspešnost' v rozlíšení pravdivých a nepravdivých výpovedí sa pohybuje na úrovni 63 až $71 \% .{ }^{141}$ Pri výskumoch v teréne - na reálnych prípadoch CSA, ktorých pravdivost' (ground truth) bola ustálená bud' rozsudkom, priznaním páchatel’a, medicínskymi nálezmi alebo detektorom lži - miera správnych rozlíšení pravdivej a nepravdivej výpovede dosiahla úroveň 90,2 \% ${ }^{142}$ Správnost' rozlíšení v laboratórnych podmienkach a v časti prípadov v teréne je síce výrazne nad úrovňou náhody, ale miera chybovosti zostáva stále značne vysoká, resp. nejasná pretože neexistujú dáta ohl'adne spol'ahlivosti SVA metódy v reálnych životných prípadoch. ${ }^{143}$ Preskúmanie presnosti SVA metódy v prípadoch z reálneho života by si vyžadovalo vediet', čo sa v každom jednom prípade skutočne stalo. Avšak dôkazy, ktoré by bezpochyby spojili alebo s istotou nespojili údajného páchatel'a s trestným činom, často chýbajú. ${ }^{144}$ Všeobecný problém terénnych výskumov zameraných na odhalenie klamstva je, že výskumníci nevedia, čo sa skutočne v daných prípadoch stalo. ${ }^{145}$ Výsledky azda najnovšieho terénneho výskumu opätovne zdôrazňujú, že CBCA je nástroj na meranie miery vierohodnosti výpovede, avšak neumožňuje identifikovat' nepravdivé výpovede; autori štúdie preto apelujú na potrebu zvýšenia validity CBCA. ${ }^{146}$

Znalcom, ktorí sa zaoberajú posudzovaním vierohodnosti výpovede údajnej obete CSA, Otgaar et al. adresujú tri odporúčania: ${ }^{147}$

1. Budovanie scenárov (scenario-building). Na začiatku práce (ešte pred čítaním spisu) je potrebné postulovat' minimálne dva scenáre: (1) že výpoved' sa zakladá na autentických zážitkoch; a (2) že výpoved’ je vyfabrikovaná. Takýto prístup môže znížit' riziko konfirmačného skreslenia (pozri subkapitolu 3.1). Po prečítaní celého spisu možno doplnit' d’alšie prieskumné (exploratory) scenáre. Úlohou znalca je posúdit', prvky ktorého scenára sa s väčšou pravdepodobnost'ou v danom prípade vyskytujú.

139 PAZ-ALONSO, Pedro M., Christin M. OGLE a Gail S. GOODMAN. Children's Memory in "Scientific Case Studies" of Child Sexual Abuse: A Review. In: COOPER, Barry S., Dorothee GRIESEL a Marguerite TERNES (eds.). Applied Issues in Investigative Interviewing, Eyewitness Memory, and Credibility Assessment. New York: Springer, 2013, s. 143-171. ISBN 9781461455462.

140 CYR a BRUNEAU, op. cit.

141 AMADO et al., op. cit., s. 3-12; VRIJ a GANIS, op. cit., s. 301-374.

142 AMADO et al., op. cit., s. 3-12.

143 VRIJ, 2015, op. cit., s. 3-35.

144 Ibid.

145 VRIJ, 2015, op. cit., s. 3-35; PAZ-ALONSO et. al., op. cit., s. 143-171.

146 WELLE, Ida, Michel BERCLAZ, Marie-Josee LACASA a Gerard NIVEAU. A call to improve the validity of criterion-based content analysis (CBCA): Results from a field-based study including 60 children's statements of sexual abuse. Journal of Forensic and Legal Medicine, 2016, roč. 43, s. 111-119.

147 OTGAAR, Henry, Corine DE RUITER, Mark L. HOWE, Lisanne HOETMER a Patricia VAN REEKUM, P. A Case Concerning Children's False Memories of Abuse: Recommendations Regarding Expert Witness Work. Psychiatry. Psychology and Law, 2017, roč. 24, č. 3, s. 365-378. 
2. Preskúmanie okolnosti prvého vyhlásenia (statement). Po vytvorení rôznych scenárov by sa znalec mal sústredit' na okolnosti prvého vyhlásenia. Pokial’ sa objavilo spontánne, bez navádzajúceho dopytovania, je s väčšou pravdepodobnost’ou presné.

3. Podrobenie konceptu (draft) posudku nezávislej recenzii. Koncept znaleckého posudku by mal prečítat' expert, ktorý nebude vediet', čiu prácu hodnotí a zároveň ani hodnotený by nemal vediet', kto je recenzentom. Úlohou recenzenta je preskúmat' koncept a v prípade potreby uviest' kritické pripomienky. Ide o d'alšiu stratégiu na minimalizáciu kontaminujúceho vplyvu konfirmačného skreslenia. Recenzent teda kriticky kontroluje, či znalec na podporu svojich scenárov a záverov starostlivo použil vedeckú literatúru a informácie v spise. ${ }^{148}$

Otgaar et al. ${ }^{149}$ konštatujú, že uplatňovanie týchto odporúčaní v praxi môže prispiet' k zvýšeniu objektivity posudkov, aj ked' plnú objektivitu zaručit' nedokáže. Iní autori ${ }^{150}$ podotýkajú, že za účelom poskytovania alternatívnych perspektív a vyvažovania individuálnych predsudkov v procese posúdenia (assessment) prípadov môže byt' užitočný predovšetkým multidisciplinárny tímový prístup. Chybné závery (mylne pozitívne alebo mylne negatívne) postavené na subjektivite a predsudkoch hodnotitel'a, môžu zdevastovat' životy dotknutých osôb. ${ }^{151}$

\subsection{Výpoved’ o minulosti nie je izolovaná od aktuálneho kontextu}

Je potrebné reflektovat' skutočnost', že spomínanie je sociálno-komunikačný akt, ktorého kvalitu ovplyvňuje nielen to, kto, kedy a na čo spomína, ale aj to, akému účelu má spomínanie slúžit', $\mathrm{v}$ akom prostredí k nemu dochádza, a aká sociálna dynamika v ňom pôsobí. ${ }^{152}$ Neexistujú žiadne univerzálne kritéria pre hodnotenie pravdivosti spomienok; ich význam, presnost’ a reliabilita závisia na hodnotiacich kritériách, ktoré sa aplikujú v konkrétnom prostredí (napr. hodnotenie traumatických spomienok na CSA je v kontexte psychoterapeutického sedenia odlišné než na súde). ${ }^{153}$ Ked’že zvyčajne nemáme prístup $\mathrm{k}$ plnému rozsahu historických dát, na ktorých sa dané spomienky zakladajú, všetky hodnotenia pravdivosti spomienok sú len provizórne. ${ }^{154}$

\footnotetext{
148 Takýto prístup (nezávislé recenzovanie konceptu posudkov) je bežnou praxou medzi holandskými forenznými psychológmi (OTGAAR et al., op. cit., s. 365-378).

149 Ibid.

150 Napr. EVERSON a SANDOVAL, op. cit., s. 287-298.

151 Ibid.

152 BRESCO DE LUNA, Ignacio. From Mind to Context, from Accuracy to Meaning. Exploring the Grammar of Remembering as a Socially Situated Act. Integrative Psychological and Behavioral Science, 2016, roč. 50, č. 2, s. 320-332. DOI: 10.1007/s12124-016-9345-7; BROWN, Steven D. a Paula REAVEY. False memories and real epistemic problems. Culture \& Psychology, 2017, roč. 23, č. 2, s. 171-185.

153 Ibid.

154 BROWN a REAVEY, op. cit., s. 171-185.
} 
Pri akejkol'vek snahe správne, ,identifikovat““ obete a páchatel’ov CSA podl'a toho, kto akú verziu príbehu rozpráva, treba tiež zohl'adňovat', že spomínanie je rekonštruktívny proces $^{155}$, ktorý nemôže byt' ani neutrálny ani objektívny. Minulé skúsenosti nemajú fixný význam. Presnost' spomínania je podriadená významu, aký minulé udalosti majú vo vzt'ahu $\mathrm{k}$ našim ciel'om a aktuálnemu konaniu. Pridelenie nového významu minulosti neznamená nevyhnutne jej falzifikáciu, ale iba jej situovanie do širšej interpretačnej schémy, ktorá v čase zážitku nemusela byt' dostupná. Preto človek môže o minulých skúsenostiach rozprávat' odlišný príbeh v rozličných momentoch a sociálnych kontextoch. ${ }^{156}$ Odhal'ovanie pravdy môže byt' chápané ako proces, ktorý sa vyvíja v čase. ${ }^{157}$ Značná čast' reálnych obetí až s odstupom času dospeje k porozumeniu, že to, čo sa stalo malo charakter zneužívania a väčšina reálnych páchatel’ov bude svoje skutky popierat' a tvrdit', že sú obet'ami krivého obvinenia ${ }^{158}$ dokonca aj vtedy, ked’ ich súd uzná vinnými. Aj vo vzt'ahu k podozreniam z CSA, ktoré sa vynoria v kontexte poručenských sporov, sa pri poctivej analýze časom ukáže, že vo väčšine prípadov napokon nejde o krivé (zlovol'né) obvinenia ale o úprimnú obavu o blaho diet'at'a. ${ }^{159}$ Ako obavy o diet'a vznikli a ako sú prežívané môže byt' klinicky dôležitejšie než obsah a pravdivost' obvinení; pre porozumenie podozreniam z CSA sa preto v takýchto prípadoch odporúča skôr dlhodobejšia psychoterapeutická intervencia než právne riešenia. ${ }^{160}$

\section{Záver}

Široká škála faktorov, ktoré ovplyvňujú presnost' pamäte (nielen u detî), činí náročným, ak nie priam nemožným, predvídat' s presnost’ou, či je výpoved' konkrétneho svedka pravdivá alebo nie; veda ešte nedospela do bodu, v ktorom by vedela ponúknut' súdom

155 Teda nie presná reprodukcia, pretože jedinec nie je iba pasívny prijímatel', uskladňovatel' a reprodukovatel' podnetov.

156 BRESCO DE LUNA, op. cit., s. 320-332.

157 BROWN a REAVEY, op. cit., s. 171-185.

158 Najjednoduchšia forma lži u páchatel’ov je popieranie skutku. Z psychologického uhla pohladu nemožno ani vylúčit', že v dôsledku mechanizmov tzv. kognitívnej disonancie a pôsobenia autosugescie páchatel' časom sám sebe uverí a bude sa cítit' ako nevinný. To tiež vysvetl'uje jeho urputnost' v boji za očistenie reputácie (ČíRTKOVÁ, 2018, op. cit., s. 12-17). - V tejto súvislosti stojí za to prečítat' si o pozadí vzniku a o kontroverzných reprezentantoch nadácie tzv. syndrómu falošnej pamäte (False Memory Syndrome Foundation) (ORR, op. cit., s. 79-94; RYDBERG, op. cit., s. 89-99). Samotný termín falošná pamät' bol konštituovaný skôr ako sociálna a politická kategória, reflektujúca záujmy určitej skupiny, než „,vedecká“ kategória, ktorá by sa opierala o vedecké dáta. Výskum zameraný na „falošné spomienky“ "v skutočnosti nepreukázal, že by bolo možné niekomu implantovat' falošné spomienky na zneužívanie $\mathrm{v}$ detstve a neponúkol ani žiadne kritéria, pomocou ktorých by bolo možné efektívne rozlísit' populáciu „pravých“ obetí od „falošných“ obetí (BROWN a REAVEY, op. cit., s. 171-185).

159 BLACK et al., op. cit., s. 482-496.

160 AWAD, George A. a Hanna McDONOUGH, H. Therapeutic management of sexual abuse allegations in custody and visitation disputes. American Journal of Psychotherapy, 1991, roč. 45, č. 1, s. 113-123; BLACK et al., op. cit., s. 482-496. DOI: 10.1176/appi.psychotherapy.1991.45.1.113 
na túto otázku konečnú odpoved’161 opierajúc sa o nejaký spol’ahlivý nástroj či metódu. ${ }^{162} \mathrm{Na}$ rozpoznanie klamstva neexistuje žiadny „lakmusový test“, žiadne zaručené triky založené na pozorovaní neverbálneho správania svedka. ${ }^{163}$ Okrem toho, ani úsudok profesionálov opierajúci sa o profesionálnu skúsenost', intuíciu či „,sedliacky rozum“164 nie je pri detekovaní klamstva - resp. posudzovaní vierohodnosti výpovede, vierohodnosti celého prípadu suspektného CSA a pri odhadoch prevalencie krivých obvinení z CSA - nijako významne spol’ahlivejší než úsudok laikov. ${ }^{165}$ Preto treba zaujat' skeptický postoj voči sebaistým úsudkom, ktoré sa v tomto ohl’ade neraz objavujúp ${ }^{166}$ tak v laických ako i odborných kruhoch.

Na mnohé otázky týkajúce sa problematiky CSA má vedecký svet už jasné odpovede, kým na iné otázky odpovede ešte stále hl’adá. Ale niekedy aj samotná rekapitulácia toho, čo už vieme a kam naše poznanie ešte nedospelo, pomáha otvárat' oči a zbavovat' sa trúfalých domnienok a predsudkov. Dúfame, že táto štúdia prispeje k reflexii problematiky krivých obvinení z CSA a snád’ aj k osvojeniu postoja pokory a bázne zoči voči prípadom podozrení z CSA, v ktorých chýbajú jasné dôkazy - prípadom, v ktorých princíp prezumpcie statusu obete nemá o nič menšie opodstatnenie než princíp pręumpcie neviny vo vzt'ahu k páchatel’ovi.

161 Otázka, či vypočúvaná osoba pri svojej konkrétnej výpovedi hovorí pravdu alebo klame, je otázkou právnou, preto ju v konečnom dôsledku musí na podklade hodnotenia dôkazov vyriešit' súd.

162 GOODMAN et al., 2017, op. cit., s. 926-939.; MELKMAN et al., op. cit., s. 76-85; CYR a BRUNEAU, op. cit.

163 ZAJAC, Rachel a Deirdre A. BROWN. Conducting Successful Memory Interviews with Children, Child \& adolescent social work, journal, 2018, roč. 35, č. 3, s. 297-308.

164 Odvolávanie sa na sedliacky rozum sa objavuje napr. v nedávno uverejnenom rozhovore so skúsenou českou policajnou vyšetrovatel'kou, ktorá tvrdí, že v kontexte rozvodov/rozchodov rodičov je drvivá väčšina obvinení zo zneužívania detí falošná (KOZELKA, Petr. Vyšetrovatelka: Proč jsou rozvádějicí se otcové take často obviňováni ze zneuživáni dětí [online]. 2018 [cit. 26.4.2018]. Dostupné z: https://www.novinky. cz/domaci/469690-vysetrovatelka-proc-jsou-rozvadejici-se-otcove-tak-casto-obvinovani-ze-zneuzivani-deti.html).

165 O’DONOHUE a CIRLUGEA, op. cit, s. 291; O’DONOHUE et al., op. cit, s. 261; MELKMAN et al., op. cit., s. $76-85$.

166 O'DONOHUE a CIRLUGEA, op. cit, s. 291; O’DONOHUE et al., op. cit, s. 261. 